\title{
NULIDAD DE LA ACTUACIÓN FUNDADA EN VIOLACIÓN AL DEBIDO PROCESO POR ACTUACIONES DE LA FISCALÍA GENERAL DE LA NACIÓN EN LA DELEGACIÓN Y ASIGNACIÓN DE FUNCIONARIOS JUDICIALES ESPECIALES PARA LA INVESTIGACIÓN Y ACUSACIÓN EN EL PROCESO PENAL
}

\author{
Carlos Arturo Gómez Pavajeau* \\ María Marta Gómez Barranco**
}

Resumen: Los actos administrativos proferidos por la Fiscalía General de la Nación no son inmunes al control natural de un Estado de Derecho. Es así

Profesor Titular de Pregrado, Especialización y Maestría en Derecho Penal y Disciplinario de la Universidad Externado de Colombia. Consultor de la Escuela Judicial "Rodrigo Lara Bonilla" y Coordinador de Barras Académicas de la Defensoría del Pueblo. Bogotá, Colombia. Correo-e: gomezpavajeau@hotmail.com

** Abogada de la Universidad Externado de Colombia y Especialista en Derecho Penal y Criminología de la misma casa de estudio. Miembro del grupo de investigación de la oficina privada del coautor. Bogotá, Colombia. Correo-e: mmgb24@hotmail.com. Fecha de recepción: 25 de abril de 2017. Fecha de aceptación: 15 de enero de 2018. Para citar el artículo: CARLos Arturo GómEz PAVAJEAU, MARÍA MARTA Gómez BARRANCO. "Nulidad de la actuación fundada en violación al debido proceso por actuaciones de la Fiscalía General de la Nación en la delegación y asignación de funcionarios judiciales especiales para la investigación y acusación en el proceso penal", en Revista Derecho Penal y Criminología, Vol. 38, n. ${ }^{\circ}$ 105, julio-diciembre de 2017, Bogotá, Universidad Externado de Colombia, pp. 37-75. DOI: https://doi.org/10.18601/01210483.v38n105.03 
como aquellos relacionados con la delegación y asignación de fiscales especiales se encuentran regidos por los principios de legalidad y debido proceso, controlables por la jurisdicción contenciosa administrativa, pero también por los jueces penales competentes, a través de los cuales se juzgan sus vicisitudes. La nulidad desempeña un papel importante en el control del ejercicio de la acción penal en tanto expresión de control de un acto administrativo, sujeto necesaria e inescindiblemente a la legalidad y al debido proceso.

Palabras clave: Autoridad judicial, Autoridad administrativa, Actos administrativos expedidos por autoridades judiciales, Delegación y asignación de fiscales especiales, Legalidad, Debido proceso, Juez natural en sentido amplio, Juez natural en sentido estricto, Irregularidad, Nulidad y autoridad competente para reconocerla.

\title{
NULLITY OF THE ACTION BASED ON VIOLATION OF DUE PROCESS FOR ACTIONS OF THE ATTORNEY GENERAL OF THE NATION IN THE DELEGATION AND ASSIGNMENT OF SPECIAL JUDICIAL OFFICERS FOR INVESTIGATION AND PROSECUTION IN CRIMINAL PROCEEDINGS
}

\begin{abstract}
The administrative acts issued by the Attorney General's Office are not immune to the natural control of a State of Law. Thus, those related to the delegation and assignment of special prosecutors are governed by the principles of legality and due process, controllable by the administrative contentious jurisdiction, but also by the competent criminal courts, through which the vicissitudes are judged. The nullity plays an important role in the control of the exercise of criminal action as an expression of control of an administrative act, a necessary and undeniable subject to legality and due process.
\end{abstract}

Keywords: Judicial Authority, Administrative Authority, Administrative acts issued by Judicial Authorities, Delegation and Assignment of Special Prosecutors, Legality, Due Process, Natural Judge in the Broad Sense, Natural Judge in the Strict Sense, Irregularity, Nullity and Competent Authority to recognize it.

\section{INTRODUCCIÓN}

En importante y trascendental Sentencia C-873 de 2003 la Corte Constitucional ha señalado, de manera clara y perentoria, que

a) Solo el Fiscal General de la Nación puede designar funcionarios especiales o hacer delegaciones de tal orden; b) Deberá exponer en forma "concreta, en 
cada caso, los hechos que motivan su decisión, esto es, que "que se adopte esta determinación mediante resolución motivada"; y, c) Deberá notificar por un medio idóneo dicha decisión a los sujetos procesales, es decir, “debidamente notificada".

Ante afirmaciones tan significativas cabe preguntarse:

¿Los actos administrativos que profiere la Fiscalía General de la Nación son de libre configuración o regidos por facultades meramente discrecionales?

¿Si una resolución administrativa emanada de la Fiscalía General de la Nación no cumple con los requisitos anunciados, por demás acumulativos, se infringe el principio fundamental del debido proceso?

¿Si, por otro lado, una designación especial para investigar a un aforado bien constitucional o legalmente, se extiende en su ejecución a un no aforado, por el fiscal especial, sin afirmación expresa para ello en el acto administrativo, se infringe el debido proceso?

El inciso 29 de la Carta Política señala de manera clara y perentoria que "el debido proceso se aplicará a toda clase de actuaciones judiciales y administrativas", independiente de la posición formal que ocupe el ente oficial en la división de los poderes públicos. De allí que, a la Fiscalía General de la Nación, como quiera que hace parte de la Rama Judicial, en tanto se ubica en el Capítulo 6 del Título VIII, "DE LA RAMA JUDICIAL", se le aplican los principios consignados en los artículos 228, 229 y 230 ibídem, así como los contenidos en la Ley Estatutaria de la Administración de Justicia, empero, como profiere actos administrativos y decisiones judiciales, unos y otros tienen que someterse al debido proceso, por mandato expreso del artículo 29 de la Carta Política, debido proceso que implica transparencia, objetividad, legalidad, imparcialidad y respeto por las reglas del ejercicio del poder público, como en múltiples ocasiones lo ha señalado la jurisprudencia constitucional.

La nulidad constitucional no tiene dependencia legal, se reitera en el concepto de debido proceso en aspectos sustanciales, o sea, en materia de derechos fundamentales como se establece en el artículo 457 del Código de Procedimiento Penal, en armonía con el 228 de la Constitución.

Los conceptos de garantías procesales, entre ellos el del debido proceso, dan cuenta de derechos y libertades constitucionales fundamentales, según la Asamblea Nacional Constituyente. Derechos que se caracterizan por tener naturaleza funcional, esto es, son diseñados con propósito protector de orden técnico, a lo cual apuntan los mecanismos procesales instrumentales para ello, en tanto emanaciones del concepto de dignidad de la persona como fundamento de todos los derechos, por lo cual implican el nacimiento de obligaciones de hacer por parte del Estado, puesto que 
la Constitución no solo es guía, sino principalmente tiene carácter vinculante. Lo que comporta reconocer que tiene "dientes", toda vez que "un derecho sin un instrumento, para que ese derecho sea exigible realmente es una mera ilusión... es una farsa". Son principios rectores o normas rectoras que no pueden ser desconocidos. Fue contundente el constituyente en reconocer que "el principio madre de todo el procedimiento" es el debido proceso, aplicable a "todos los procedimientos, administrativos o judiciales", de lo cual "no quede la menor duda", de tal manera que "se ha garantizado siempre ese derecho a que los procesos tengan unos trámites que se cumplan", puesto que lo contrario sería tanto como "consagrar la arbitrariedad permanente en un proceso penal" 1 .

El debido proceso es un concepto superior al de fórmulas propias del juicio, como lo reconoció paladinamente la Asamblea Nacional Constituyente, habida cuenta de que la segunda es restringida, daría cuenta de los procedimientos ante el juez quien es el que tramita el juicio. Pero el debido proceso como aspecto objetivo es una "garantía del orden de la justicia, de la seguridad", su aspecto sustantivo en cuanto garantías, que protegen al ciudadano sometido al proceso penal. El concepto de debido proceso es más amplio que el de fórmula de juicio, es "rico y diciente", puesto que "proceso puede ser todo, pero juicio es juicio, pero juicio necesita el juez, el proceso no", de manera que la garantía cubre lo que se ha entendido como sumario y juicio, toda vez que "el proceso es el que está garantizado totalmente" y abarca, con sentido propio, "toda la juridicidad colombiana" en "toda clase de litigio y trámites administrativos", "el debido proceso es para toda clase de actuaciones" dado su carácter de formas "sustanciales", tal como debe ser en "una carta política democrática y liberal, ciento por ciento liberal en el más noble sentido del vocablo"2.

Concordante con ello, la Corte Constitucional tiene dicho que la noción de "debido proceso, como derecho fundamental, no se agota en el principio de legalidad", toda vez que se identifica con el respeto de las garantías y por supuesto con la noción de "procedimiento justo" o con los "elementos que definen el carácter justo del mismo"3. El debido proceso material implica "el derecho a que existan procedimientos adecuados, idóneos y efectivos para la definición de las pretensiones y excepciones debatidas", pero también debe resaltarse que "la consagración de los recursos y procedimientos no puede ser solamente formal sino que deben cumplir su finalidad, esto es, deben resultar eficaces"4.

Por tanto, si el debido proceso ha sido entendido como "una limitación al poder punitivo del Estado" y como tal comprende "el conjunto de garantías sustanciales y

1 Asamblea Nacional Constituyente, Comisión Primera, sesión de abril 15 de 1991.

2 Asamblea Nacional Constituyente, Comisión Primera, sesión de abril 15 de 1991.

3 Corte Constitucional, Sentencia T-116 de 2004.

4 Ídem, Sentencia C-985 de 2005. También las Sentencias C-564 y C-662 de 2004. 
procesales especialmente diseñadas para asegurar la legalidad, regularidad y eficacia de la actividad jurisdiccional en la investigación y juzgamiento de los hechos"5, queda puesto de presente que no puede confundirse su concepto con el de "ritualidad procesal", habida cuenta de que va más allá de la legalidad.

Tales razones materiales, trascendentes al ritualismo procesal, han permitido afirmar con solidez que "las formas procesales no se justifican en sí mismas sino en razón del cometido sustancial al que propende la administración de justicia... Todos estos elementos integran la plenitud de las formas propias de cada juicio, contempladas como factor esencial del debido proceso y por lo tanto no constituyen simplemente reglas formales vacías de contenido sino instrumentos necesarios para que el Derecho material se realice objetivamente" 6 .

Repárese pues, como se verá más adelante, cómo una jurisprudencia penal trivializa este derecho fundamental a partir de criterios insustanciales, meramente formales, como aquel según el cual no es posible anular actos de partes, como sucedería con los actos administrativos proferidos por la Fiscalía General de la Nación antes de la judicialización de la investigación, lo que contrariaría todo lo afirmado por el constituyente, olvidando que por tal circunstancia -naturaleza de parte- no deja de ser un poder público con potencialidad real y efectiva de quebrantar el debido proceso, cuando los derechos fundamentales, como lo dice la misma Asamblea Nacional Constituyente en el documento antes mencionado, imponen incluso a los particulares la obligación de respetar el debido proceso según los efectos horizontales de los mismos, dada la correlatividad entre derechos y deberes: "No estamos haciendo un catálogo de los derechos para que los respete el Estado, sino para que los respeten los particulares, y el Estado garantiza que el particular también respete los derechos". Así se estableció en la Sentencia T-276 de 2014 de la Corte Constitucional, de manera que el debido proceso no está excluido de ninguna actuación, ni pública ni privada.

Precisamente por ello, el Artículo 10 de la Ley 906 de 2004, como principio rector, no distingue en la clase de actuación procesal y demanda en todas sin excepción la prevalencia del derecho sustancial al debido proceso. Lo contrario sería desconocer los mandatos de los artículos 26 y 27 ibídem, que dotan al 10 de materialidad y por supuesto excluyen los ritos por los ritos, o lo que se denomina el exceso ritual manifiesto ${ }^{7}$.

Si el debido proceso tiene que ver con la juridicidad, como lo expresa la Asamblea Nacional Constituyente, allí debe encontrarse el sentido del artículo 115 de la Ley 906 de 2004, cuando manda objetividad y transparencia, pero especialmente criterio

5 Ídem, Sentencias T-039 de 1996 y C-948 de 2002.

6 Ídem, Sentencia T-323 de 1999.

7 Ídem, sentencias T-264 de 2009, T-599 de 2009, T-429 de 2011 y T-950 de 2011. 
"ajustado jurídicamente" a la Carta Política y la ley en las actuaciones de la Fiscalía General de la Nación. Es la prueba irrefutable de que el debido proceso se aplica también a la actuación administrativa llevada a cabo por la Fiscalía General de la Nación en el proceso penal, lo cual es por demás un principio rector en la Teoría General del Proceso, de conformidad con el artículo 14 del Código General del Proceso.

Si el artículo 339 de la Ley 906 de 2004 señala que en la audiencia de formulación de acusación la defensa podrá proponer "nulidades, si las hubiere" y la jurisprudencia afirma que no se pueden nulitar las actuaciones de la Fiscalía por ser parte ${ }^{8}$, cuáles otras entonces son esas nulidades que permite la norma interponer en esta etapa procesal, diferentes a los actos de la Fiscalía, si es verdad de Perogrullo que son los únicos existentes como tal, con lo que tal interpretación conllevaría que se perdiera de manera absoluta el efecto útil de la norma, despojando de sustancialidad al debido proceso, en los términos concebidos por la Asamblea Nacional Constituyente.

Podría pensarse que las nulidades de que allí se habla son aquellas que respecto de las pruebas da cuenta el inciso final del Artículo 29 de la Carta Política, no obstante, ello es una forma particular y excepcional del quebrantamiento del debido proceso, que se reclama en la audiencia preparatoria según los artículos 359 y 360 de la Ley 906 de 2014. Es más, el inciso final mencionado es la demostración irrefutable de que los actos de la Fiscalía pueden devenir en inválidos o ineficaces, bien por nulidad o por inexistencia, muy especialmente por cuanto el Artículo 457 ibídem no limita las nulidades exclusiva y excluyentemente a la etapa del juicio, rigiendo la regla según la cual, donde el legislador no distingue, no le es dable hacerlo al intérprete, aspectos plenamente coincidentes con lo expuesto por la Asamblea Nacional Constituyente.

Sobre las garantías antes mencionadas, consagradas en tratados internacionales sobre Derechos Humanos, para los efectos del principio rector sobre la prevalencia de tratados internacionales -artículo 3 del C. de P.P.-, tiene dicho la Corte Interamericana de Derechos Humanos en los siguientes párrafos:

147. El artículo 8 de la Convención Americana se aplica al conjunto de requisitos que deben observarse en las instancias procesales, cualesquiera que ellas sean, a efecto de que las personas puedan defenderse adecuadamente ante cualquier acto emanado del Estado que pueda afectar sus derechos ${ }^{9}$.

8 Al menos así se ha pronunciado respecto de los cuestionamientos al escrito de acusación o al acto de acusación o de los actos de investigación o del procedimiento investigativo por la Fiscalía General de la Nación, como se puede apreciar muy puntualmente en SARAY Botero, NeLSON, Procedimiento Penal Acusatorio. Bogotá, UniAcademia Leyer, 2017, pp. 557 a 559 y 563 a 565.

9 Cfr. Caso Ivcher Bronstein. Sentencia de 6 de febrero de 2001. Serie C n. ${ }^{\circ}$ 74, párr. 102; Caso Baena Ricardo y otros. Sentencia de 2 de febrero de 2001. Serie C n. ${ }^{\circ} 72$, párr. 124; Caso del Tribunal Constitucional. Sentencia de 31 de enero de 2001. Serie C n. ${ }^{\circ} 71$, párr. 69; y Garantías Judiciales 
148. De acuerdo a lo dispuesto en el artículo 8.1 de la Convención, en la determinación de los derechos y obligaciones de las personas, de orden penal, civil, laboral, fiscal o de cualquier otro carácter, se deben observar "las debidas garantías" que aseguren, según el procedimiento de que se trate, el derecho al debido proceso.

149. Todos los órganos que ejerzan funciones de naturaleza materialmente jurisdiccional tienen el deber de adoptar decisiones justas basadas en el respeto pleno a las garantías del debido proceso establecidas en el artículo 8 de la Convención Americana ${ }^{10}$. El artículo 8.1 de la Convención, que alude al derecho de toda persona a ser oída por un "juez o tribunal competente" para la "determinación de sus derechos", es igualmente aplicable al supuesto en que alguna autoridad pública, no judicial, dicte resoluciones que afecten la determinación de tales derechos ${ }^{11}$, como ocurrió en el presente caso ${ }^{12}$ (resaltado fuera de texto).

Más recientemente recalcó, como para que no existiese duda de ello:

... [t]odos los órganos que ejerzan funciones de naturaleza materialmente jurisdiccional tienen el deber de adoptar decisiones justas basadas en el respeto pleno a las garantías del debido proceso establecidas en el artículo 8 de la Convención Americana. El artículo 8.1 de la Convención, que alude al derecho de toda persona a ser oída por un "juez o tribunal competente" para la "determinación de sus derechos", es igualmente aplicable al supuesto en que alguna autoridad pública, no judicial, dicte resoluciones que afecten la determinación de tales derechos ${ }^{13}$ (resaltado fuera de texto).

Además la Corte Interamericana de Derechos Humanos tiene dicho sobre ello:

El principio de la protección igualitaria y efectiva de la ley y de la no discriminación constituye un dato sobresaliente en el sistema tutelar de los derechos

en Estados de Emergencia (arts. 27.2, 25 y 8 Convención Americana sobre Derechos Humanos). Opinión Consultiva OC-9/87 del 6 de octubre de 1987. Serie A n. ${ }^{\circ}$ 9, párr. 27.

10 Cfr. Corte Interamericana de Derechos Humanos Caso Ivcher Bronstein, supra nota 141, párr. 104; y Caso del Tribunal Constitucional, supra nota 141, párr. 71.

11 Cfr. Caso Ivcher Bronstein, supra nota 141, párr. 105; y Caso del Tribunal Constitucional, supra nota 141 , párr. 71.

12 Corte Interamericana de Derechos Humanos, sentencia de junio 23 de 2005, Caso Yatama Vs. Nicaragua.

13 Corte Interamericana de Derechos Humanos, sentencia de agosto 5 de 2008, Caso Apitz Barbera y otros vs. Venezuela, párr. 46. 
humanos consagrado en muchos instrumentos internacionales ${ }^{14} \mathrm{y}$ desarrollado por la doctrina y jurisprudencia internacionales. En la actual etapa de la evolución del derecho internacional, el principio fundamental de igualdad y no discriminación ha ingresado en el dominio del jus cogens. Sobre él descansa el andamiaje jurídico del orden público nacional e internacional y permea todo el ordenamiento jurídico ${ }^{15}$ (resaltado fuera de texto).

14 Algunos de estos instrumentos internacionales son: Carta de la OEA (artículo 3.1); Convención Americana sobre Derechos Humanos (artículos 1 y 24); Declaración Americana de los Derechos y Deberes del Hombre (artículo II); Protocolo Adicional a la Convención Americana sobre Derechos Humanos en Materia de Derechos Económicos, Sociales y Culturales, "Protocolo de San Salvador" (artículo 3); Convención Interamericana para Prevenir, Sancionar y Erradicar la Violencia contra la Mujer (artículos 4.f, 6 y 8.b); Convención Interamericana para la Eliminación de Todas las Formas de Discriminación contra las Personas con Discapacidad (artículos I.2.a, II, III, IV y v); Carta de las Naciones Unidas (artículo 1.3); Declaración Universal de Derechos Humanos (artículos 2 y 7); Pacto Internacional de Derechos Económicos, Sociales y Culturales (artículos 2.2 y 3); Pacto Internacional de Derechos Civiles y Políticos (artículos 2.1 y 26); Convención Internacional sobre la Eliminación de todas las Formas de Discriminación Racial (artículo 2); Convención sobre los Derechos del Niño (artículo 2); Declaración de los Derechos del Niño (Principio 1); Convención Internacional sobre la Protección de los Derechos de Todos los Trabajadores Migratorios y de sus Familiares (artículos 1.1, 7, 18.1, 25, 27, 28, 43.1 , 43.2 , 45.1, 48, 55 y 70); Convención sobre la Eliminación de Todas las Formas de Discriminación contra la Mujer (artículos 2, 3, 5, 7 a 16); Declaración sobre la Eliminación de Todas las Formas de Intolerancia y Discriminación Fundadas en la Religión o las Convicciones (artículos 2 y 4); Declaración de la Organización Internacional del Trabajo (OIT) relativa a los Principios y Derechos Fundamentales en el Trabajo y su Seguimiento (2.d); Convenio n. ${ }^{\circ} 97$ de la Organización Internacional del Trabajo (OIT) sobre los Trabajadores Migrantes (revisado) (artículo 6); Convenio n. ${ }^{\circ} 111$ de la Organización Internacional del Trabajo (OIT) relativo a la Discriminación en Materia de Empleo y Ocupación (artículos 1 a 3); Convenio n. ${ }^{\circ} 143$ de la Organización Internacional del Trabajo (OIT) sobre los Trabajadores Migrantes (disposiciones complementarias) (artículos 8 y 10); Convenio n. ${ }^{\circ} 168$ de la Organización Internacional del Trabajo (OIT) sobre el Fomento del Empleo y la Protección contra el Desempleo (artículo 6); Proclamación de Teherán, Conferencia Internacional de Derechos Humanos de Teherán, 13 de mayo de 1968 (párrs. 1, 2, 5, 8 y 11); Declaración y Programa de Acción de Viena, Conferencia Mundial de Derechos Humanos, 14 a 25 de junio de 1993 (I.15; I.19; I.27; I.30; II.B.1, artículos 19 a 24; II.B.2, artículos 25 a 27); Declaración sobre los Derechos de las Personas Pertenecientes a Minorías Nacionales o Étnicas, Religiosas y Lingüísticas (artículos 2, 3, 4.1 y 5); Conferencia Mundial contra el Racismo, la Discriminación Racial, la Xenofobia y las Formas Conexas de Intolerancia, Declaración y Programa de Acción, (párrafos de la Declaración: 1, 2, 7, 9, 10, 16, 25, 38, 47, 48, 51, 66 y 104); Convención Relativa a la Lucha contra las Discriminaciones en la Esfera de la Enseñanza (artículos 1, 3 y 4); Declaración sobre la Raza y los Prejuicios Raciales (artículos 1, 2, 3, 4, 5, 6, 7, 8 y 9); Declaración sobre los Derechos Humanos de los Individuos que no son Nacionales de País en que Viven (artículo 5.1.b y 5.1.c); Carta de los Derechos Fundamentales de la Unión Europea (artículos 20 y 21); Convenio Europeo para la Protección de los Derechos Humanos y de las Libertades Fundamentales (artículo 14); Carta Social Europea (artículo 19.4, 19.5 y 19.7); Protocolo n. ${ }^{\circ} 12$ al Convenio Europeo para la Protección de los Derechos Humanos y de las Libertades Fundamentales (artículo 1); Carta Africana de los Derechos Humanos y de los Pueblos "Carta de Banjul" (artículos 2 y 3); Carta Árabe sobre Derechos Humanos (artículo 2); y Declaración de El Cairo sobre Derechos Humanos en el Islam (artículo 1).

15 Corte Interamericana de Derechos Humanos, sentencia de junio 23 de 2005, Caso Yatama vs. Nicaragua, párr. 184 . 
En términos generales, la infracción al debido proceso está dada por el desconocimiento de las normas que regulan y gobiernan los procedimientos, de tal manera que, como lo dice la Corte Constitucional, "si el proceso fue irregular y se desconocieron garantías, existirá un vicio que conducirá a la nulidad de la actuación desarrollada"16 (resaltado fuera de texto).

Teniendo en cuenta la jurisprudencia constitucional, que ha precisado que el debido proceso comporta la necesidad de atenerse, por parte de cualquier autoridad pública, judicial o administrativa como lo dice el inciso $1^{\circ}$ del artículo 29 de la Carta Política, a las preceptivas del debido proceso, "el cual debe señalar las pautas que procuren el respeto de los derechos y obligaciones de las partes procesales para que ninguna actuación de las autoridades tenga origen en su propio arbitrio" ${ }^{17}$, cualquier conculcamiento del mismo en términos sustanciales, bien en el ejercicio de funciones administrativas o judiciales por parte de la Fiscalía General de la Nación, se constituye en irregularidad procesal trascendente a nulidad.

La nulidad de actuaciones llevadas a cabo por la Fiscalía General de la Nación tiene claro soporte en los artículos 359, 360 y 457 de la Ley 906 de 2004, como también en los artículos 42 , numerales $5^{\circ}$ y 12 -el juez tiene el deber de "realizar el control de legalidad de la actuación procesal una vez agotada cada etapa del proceso"-, y 132 del Código General del Proceso, que contempla el control de legalidad una vez termine cada etapa procesal, sin distinguir el tipo de naturaleza de la misma, como lo entendió la Asamblea Nacional Constituyente, refrendado por el artículo 25 de la Ley 1285 de 2009, con rango de Ley Estatutaria de la Administración de Justicia, según se estableció por la Corte Constitucional en Sentencia C-633 de 1996.

\section{VIOLACIÓN AL DEBIDO PROCESO POR FALTA DE FORMACIÓN Y TRÁMITE COMO TAMBIÉN DE LA NOTIFICACIÓN, DE LA ACTUACIÓN ADMINISTRATIVA QUE DA ORIGEN A UNA ASIGNACIÓN O DESIGNACIÓN DE FUNCIONARIO ESPECIAL}

El artículo 4 de la Ley 1437 de 2011 consagra las formas de iniciar las actuaciones administrativas, siendo las pertinentes, la de obrar la autoridad en cumplimiento de una obligación o deber legal u oficiosamente (numerales $3^{\circ}$ y $4^{\circ}$ ). Como no existe regulación específica en norma alguna de cómo se llevan a cabo los actos administrativos mencionados al interior de la Fiscalía General de la Nación, salvo en lo que tiene que ver con la competencia para decidirlos, el aplicable es el procedimiento

16 Corte Constitucional, Sentencia C-537 de 2016. Fundamento Jurídico n. ${ }^{\circ} 34$.

17 Ídem, Sentencia T-073 de 1997. 
administrativo común y principal que establece la ley mencionada, tal como lo dispone su Artículo 34.

Como se trata de un procedimiento de oficio, en cumplimiento de deberes constitucionales y legales, el trámite debe ser escrito y por tanto debe constar en documentos la actuación llevada a cabo, sobre todo el cumplimiento del deber de "informar de la iniciación de la actuación al interesado para el ejercicio del derecho de defensa", según el imperativo categórico que emana del artículo 35 de la Ley 1137 de 2011. Si eventualmente apareciera un tercero, con el fin de hacer valer sus derechos, también debe procederse de conformidad (Artículo 37 ibídem), en tanto su omisión comporta clara afectación de los derechos de los procesados, lo que reclama la intervención correctora de la judicatura a la luz del numeral $2^{\circ}$ del Artículo 38 ibídem.

Si se procede en contravía de dichos preclaros principios de la actuación administrativa, regulados en el Artículo 3 de la Ley 1137 de 2011, especialmente el del debido proceso de que da cuenta su numeral $1^{\circ}$, mediante el cual se señala que "las actuaciones administrativas se adelantarán de conformidad con las normas de procedimiento y competencia establecidas en la Constitución y la ley, con plena garantía de los derechos de representación, defensa y contradicción", la irregularidad trasciende irremisiblemente a nulidad.

Todas las normas anteriores, sin duda alguna de carácter administrativo, deben ser cumplidas por una autoridad judicial como lo es la Fiscalía General de la Nación, según la jurisprudencia de la Corte Interamericana de Derechos Humanos, de la Corte Constitucional y del Artículo 29 de la Carta Política, en armonía con los artículos 228, 229 y 230 de la misma como se vio, habida cuenta de que son normas constitutivas del debido proceso administrativo y particularmente integradas al proceso penal, sin posibilidad alguna de distinguir en unas u otras para efectos de enervar sofísticamente el reconocimiento de vicios que se quieren ocultar, de tal modo que no reconocerles su relevancia jurídica, nos ubicaría bajo el manto de un exceso ritual manifiesto.

El Consejo de Estado determinó que las resoluciones que profiere el Fiscal General de la Nación en materia de asignaciones especiales y delegaciones especiales son actos administrativos y, como tal, deben seguir las reglas de cualquier acto que exprese la voluntad de la administración, de conformidad con la Carta Política y la ley, sobre todo se tienen que ajustar a lo decidido en la Sentencia C-873 de 2003[18].

18 Consejo de Estado, Sala de lo Contencioso Administrativo Sección Segunda-Subsección “A”, sentencia de junio 24 de 2015, C.P.: Gómez Aranguren radicado n. . 11001-03-24-000-2011-00438-00 (1245-2013). 
Sobre el debido proceso se ha dicho por la misma Corporación, en forma concordante con la jurisprudencia en materia procesal penal, que

Como se sabe, el debido proceso, consagrado en el artículo 29 de la Constitución Política, es una garantía y un derecho fundamental de aplicación inmediata y está compuesto por tres ejes fundamentales: $i$ ) los derechos de defensa y contradicción, ii) las formas propias de cada juicio o procedimiento, y iii) la garantía del juez o funcionario competente. El desconocimiento de cualquiera de esos elementos vulnera el debido proceso siempre que la acción o la omisión sea de tal entidad que resulte insubsanable. Tratándose de las formas propias de cada juicio o procedimiento, es menester tener en cuenta que la forma alude al modo como se expide el acto administrativo, es decir, a las etapas y ritualidades de formación y expedición del acto. El procedimiento se traduce en la aplicación práctica de actos intermedios y definitivos que instrumentan la realización del fin jurídico. Las reglas del procedimiento administrativo comprenden el nacimiento, la expedición, la ejecución y la eficacia del acto administrativo. El objetivo concreto de un procedimiento administrativo es producir un acto administrativo legitimado ${ }^{19}$.

Resultaría absolutamente absurdo entender que la Jurisdicción Contenciosa Administrativa sí puede anular un acto administrativo de la Fiscalía General de la Nación cuando el mismo es constitutivo del ejercicio de la acción penal y no pueda hacerlo así el juez penal competente, encargado de velar por el respeto de las garantías constitucionales, tal como se lo ordena el numeral $2^{\circ}$ del Artículo 138 de la Ley 906 de 2004, lo cual recalca el numeral $3^{\circ}$ de su Artículo 139.

\section{VIOLACIÓN DEL DEBIDO PROCESO POR FALTA DE MOTIVACIÓN CONCRETA, SUFICIENTE Y ESPECÍFICA DEL CAMBIO DEL FUNCIONARIO JUDICIAL LLAMADO A CONOCER NATURALMENTE DEL PROCESO PENAL. ABSTRACCIÓN E INTEMPORALIDAD}

"Ninguna autoridad del Estado podrá ejercer funciones distintas de las que le atribuyen la Constitución y la ley", dice el Artículo 121, verdad inconcusa en un Estado de Derecho (artículos 1, 2 y 6 de la Carta Política).

En el ordenamiento constitucional colombiano no tiene cabida la teoría de las atribuciones o facultades implícitas, lo cual es absolutamente contrario a la Carta Política.

19 Consejo de Estado, Sala de lo Contencioso Administrativa Sección Cuarta, sentencia de marzo 5 de 2015, C.P.: Bastidas Bárcenas, radicado n. . 25000-23-27-000-2010-00208-01(19382). 
Su Artículo 6 determina la fuente de la responsabilidad de los servidores públicos por infringir sus disposiciones y las leyes, generando ilicitudes por acción, omisión y, sobre todo, por "extralimitación en el ejercicio de sus funciones". Así las cosas, todo acto de un servidor público tiene que tener amparo normativo, toda vez que no existen en un Estado de Derecho facultades y potestades implícitas, como parece ser entendido por la Fiscalía General de la Nación en su intervención en algunos procesos penales.

La jurisprudencia constitucional ha sentado los siguientes principios: i) "Quien está detentando el poder necesita estar legitimado en sus actos, y esto opera por medio de autorización legal”; ii) "Es a todas luces contrario al principio señalado, suponer que al no estar algo expresamente prohibido, bien sea para el legislativo, o para cualquier otra rama del poder público, sus integrantes pueden hacerlo, porque esta prerrogativa es exclusiva de los particulares", y iii) "Los servidores públicos tan solo pueden realizar los actos previstos por la Constitución, las leyes o los reglamentos, y no pueden, bajo ningún pretexto, improvisar funciones ajenas a su competencia", lo que en el Estado moderno se constituye en el "principio de legalidad" 20.

Ahora bien, la delegación es un mecanismo o principio organizacional a través del cual se reparte la competencia entre funcionarios del Estado dentro de la estructura administrativa, incluida la propia de las ramas judicial y legislativa del poder público, lo que presupone un superior y un inferior jerárquico, según Sentencia C-036 de 2005, proferida por la Corte Constitucional. Por tal razón, de manera clara, la Sentencia C-496 de 1998 ibídem refiere que la delegación implica "la transferencia de funciones radicadas en cabeza de los órganos administrativos superiores a instituciones u organismos dependientes de ellos".

Por el contrario, la descentralización consiste en "la facultad que se otorga a entidades diferentes del Estado para gobernarse a sí mismas, a través de la radicación de ciertas funciones en sus manos y autonomía que significa la capacidad de gestión independiente de asuntos propios" como lo establece la Sentencia C-1051 de 2001 de la Corte Constitucional. Por otro lado, la desconcentración es un "instituto jurídico que hace relación a la transferencia de potestades para la toma de decisiones, a instancias o agencias que se encuentran subordinadas al ente central, sin que necesariamente, gocen de personería jurídica, ni presupuesto, ni reglamento administrativo propio", como lo dispuso la Sentencia C-259 de 2008 de la misma corporación.

Los principios organizacionales que existen en el Estado para el ejercicio de las atribuciones públicas son los de la delegación, desconcentración y descentralización ${ }^{21}$;

20 Corte Constitucional, Sentencia C-337 de 1993.

21 Ídem, Sentencia T-024 de 1996, reiterada por sentencias C-496 de 1998, C-561 de 1999, C-727 de 2000 y C-036 de 2005. 
por lo tanto, solo en el primero de los mencionados tiene cabida la delegación y asignación de funcionarios especiales por parte de la Fiscalía General de la Nación, toda vez que los restantes dependen de su instrumentación por medio de la ley. Es en concreto la delegación y designación de funcionarios especiales, una "transferencia de competencias" entre "órganos de una misma persona jurídica", pero de "distinta jerarquía”, como se enfatiza en la Sentencia C-036 de 2005.

Dice la jurisprudencia constitucional, que la delegación implica:

(i) la transferencia de funciones de un órgano a otro; (ii) que la transferencia de funciones se realice por el órgano titular de la función; (iii) que dicha transferencia cuente con una previa autorización legal; (iv) y que el órgano que confiera la delegación pueda siempre y en cualquier momento reasumir la competencia ${ }^{22}$.

La delegación, como mecanismo de "transformación de funciones administrativas", debe observar sus "elementos constitutivos", de tal manera que allí se respete el principio de legalidad, puesto que solo puede llevarse a cabo "en los supuestos permitidos por la Ley”, según lo reclama de manera expresa, tajante y categórica la Sentencia T-024 de 1996, reiterada por las sentencias C-496 de 1998, C-561 de 1999, C-727 de 2000 y C-036 de 2005, todas de la Corte Constitucional.

Según la jurisprudencia del Consejo de Estado, "en el Estado de Derecho las competencias de las autoridades son siempre expresas, por lo cual no existen competencias implícitas, ni es viable su extensión o aplicación por vía de analogía"23 (resaltado fuera de texto).

La Sentencia T-936 de 2001 de la Corte Constitucional, determinó que la delegación se perfecciona con el proferimiento de un acto administrativo "motivado". Tal como se ordena, de manera específica y concreta para las asignaciones y delegaciones especiales, por el numeral $2^{\circ}$ del Artículo 116 de la Ley 906 de 2004, en armonía con el numeral $4^{\circ}$ del Artículo 4 del Decreto 016 de 2014.

La jurisprudencia constitucional ha señalado que

En la delegación se presentan tres clases de decisiones: $1^{\text {a }}$ ) la decisión de la autoridad que otorga la calidad de delegante a una autoridad administrativa y que señala las materias en las cuales podrá darse la delegación; 2a) la decisión

22 Ídem, Sentencia C-036 de 2005. Ver Sentencia T-024 de 1996, con criterio reiterado en las sentencias C-496 de 1998, C-561 de 1999 y C-727 de 2000.

23 Consejo de Estado, Sala Plena de lo Contencioso Administrativo, auto de agosto 2 de 2011, radicado n. ${ }^{\circ} 11001031500020100073700$. 
de delegar que toma el delegante, la cual se concreta en el acto de delegación, y $3^{\mathrm{a}}$ ) las decisiones que toma el delegatario en ejercicio de la delegación, las cuales a su vez se expresan en actos o resoluciones ${ }^{24}$ (resaltado fuera de texto).

Acorde con ello la jurisprudencia del Consejo de Estado tiene dicho:

... la delegación de funciones opera previa autorización de norma superior, por conveniencia o necesidad del servicio público y materializado a través de un acto administrativo donde se precisen las funciones a desarrollar por el delegatario, quien tiene la misma autonomía del titular de las funciones delegadas $^{25}$ (resaltado fuera de texto).

No fue mera casualidad tal postura; de hecho, se constituye en un precedente judicial de obligatorio acatamiento, puesto que ya había dicho:

Como se sabe, en materia administrativa la delegación consiste en el traslado de funciones de una autoridad a otra de igual o inferior jerarquía, previa autorización legal para hacerlo, cuya decisión se materializa o concreta en un determinado acto administrativo, en el cual se deben precisar las funciones o asuntos específicos cuya atención y decisión se transfieren (art. $9^{\circ}$ de la ley 489 de 1998), para que sean desarrolladas o ejercidas por ese otro funcionario con la autonomía de su titular, aunque, éste último conserva las facultad de reasumir en cualquier momento la función delegada, lo mismo que las de revisar y revocar los actos del delegatario ${ }^{26}$ (resaltado fuera de texto).

La doctrina, por demás recogida en la jurisprudencia administrativa, también así lo determina, al exigir que para la validez de la delegación se requiere:

a) la autorización legal previa; b) la determinación de la materia delegable; c) el traslado de la responsabilidad del superior que delega al subalterno que la recibe, y d) la capacidad para revocar la delegación ${ }^{27}$ (resaltado fuera de texto).

24 Corte Constitucional, Sentencia C-372 de 2002.

25 Consejo de Estado, Sala de lo Contencioso Administrativo, Sección Segunda Subsección “A”, sentencia de agosto 12 de 2009, C.P.: Vergara Quintero, radicación n. ${ }^{\circ}$ 25000-23-25-000-1999-0726901(4334-05).

26 Consejo de Estado, Sala de lo Contencioso Administrativo, sentencia de mayo 30 de 2000, C.P.: Rodríguez Villamizar, radicación n. ${ }^{\circ}$ AC-9877.

27 Gustavo Humberto Rodríguez citado por Younes Moreno, Diego, Curso de derecho administrativo. Bogotá, Temis, 2007, p. 24. 
Es destacable, además, como el Consejo de Estado ha señalado que no existe "delegación de la delegación" ni la subdelegación, y si ello se presenta, debe entenderse como no escrita ${ }^{28}$.

El artículo 10 del C. de P.P., principio rector que tiene prevalencia sobre las demás normas según su homólogo 26, y muy especialmente el 27 que instrumenta la función judicial en orden a "evitar excesos contrarios a la función pública", indica que la actuación procesal, sin distinguir etapas, se desarrollará teniendo en cuenta los derechos fundamentales de las personas, muy especialmente para el efecto, la más absoluta lealtad procesal y buena fe, también principio rector contenido en el artículo 12. De allí que, el artículo 115, sobre el principio de objetividad, manda con carácter de imperativo categórico a la Fiscalía General de la Nación y a los funcionarios de Policía Judicial, el adecuar "su actuación a un criterio objetivo y transparente, ajustado jurídicamente para la correcta aplicación de la Constitución Política y la ley".

La Corte Constitucional señaló, a partir del artículo 249 de la Carta Política, en su Sentencia C-873 de 2003, que a) Solo el Fiscal General de la Nación puede designar funcionarios especiales o hacer delegaciones de tal orden; b) Deberá exponer en forma "concreta, en cada caso, los hechos que motivan su decisión, esto es, que "que se adopte esta determinación mediante resolución motivada"; y, c) Deberá notificar por un medio idóneo dicha decisión a los sujetos procesales, es decir, "debidamente notificada".

La jurisprudencia penal acogió de manera expresa y explícita los puntos anteriores señalados por la Corte Constitucional, agregando que la motivación del Fiscal General debe sustentarse en "razones objetivas calificables como excepcionales"29.

De antaño se viene afirmando que las resoluciones que profiera el Fiscal General de la Nación en materia de asignaciones y asignaciones especiales no escapan al control de las autoridades jurisdiccionales, según lo establecido por el Consejo de Estado ${ }^{30}$.

Repetimos que la jurisprudencia administrativa determinó que las resoluciones que profiere el Fiscal General de la Nación en materia de asignaciones especiales y delegaciones especiales son actos administrativos y como tal, deben seguir las reglas de cualquier acto que exprese la voluntad de la administración, de conformidad con la

28 Consejo de Estado, Sala de lo Contencioso Administrativo Sección Quinta, sentencia de segunda instancia de septiembre 1 de 2016, C.P.: Bermúdez Bermúdez, radicado n. ${ }^{\circ}$ 70001-23-33-000-201500516-01.

29 Corte Suprema de Justicia, Sala de Casación Penal en sentencia de junio 22 de 2016, M.P.: Fernández Carlier, radicado n. ${ }^{\circ} 42.720$.

30 Consejo de Estado, Sala de lo Contencioso Administrativo Sección Primera, sentencia de noviembre 23 de 1993, C.P.: Ariza Muñoz, radicación n. ${ }^{\circ} 2284$. 
Carta Política y la ley, sobre todo se tienen que ajustar a lo decidido en la Sentencia C-873 de 2003 de la Corte Constitucional ${ }^{31}$.

Destacó la jurisprudencia administrativa que en tales materias no rige "una atribución meramente discrecional, ausente de los elementos de regularidad que supone las garantías de independencia y autonomía de quien ejerce funciones judiciales", debiéndose observar los "principios inherentes a la administración de justicia", recalcando que su ejercicio presupone que "deberá exponer en forma concreta, en cada caso, los hechos que motivan su decisión", fundados en razones objetivas que reflejen un carácter de excepcionalidad con el fin de "neutralizar cualquier viso de arbitrariedad o subjetividad extrema en la decisión", la cual debe ser notificada en debida forma. No atender lo anterior comporta en dichas materias dos consecuencias graves: por un lado, la mecanización irrazonable del investigador como un simple operador, a quien se lo mueve "por el mero arbitrio de un autoridad superior" y, por otro, la pérdida de independencia y autonomía.

Haciendo énfasis en el criterio esbozado por la Fiscalía en su defensa en el juicio ante el contencioso administrativo, señaló, muy a su pesar, que "si no se corrigen en su alcance interpretativo, pueden dar lugar a la inaceptable categoría de una función horizontal de un servidor público ausente de cualquier control, como si se tratara de una potestad puramente privada, en los términos del artículo 6 de la Constitución”. Debe destacarse que, al igual que lo hacen los actos administrativos aquí cuestionados, en el que fue objeto de decisión por el Consejo de Estado se había ordenado la notificación de la decisión al fiscal asignado.

El control de la actividad de la administración, bien en el campo ejecutivo como en el judicial, está sujeto inexorablemente al Estado de Derecho, ni aun escapan a dicho control, los actos administrativos que vienen sujetos a facultades discrecionales propias del Presidente de la República ${ }^{32}$.

Es verdaderamente importante esta sentencia del alto tribunal por cuanto se establece como obligatorio el Control de Convencionalidad para todas las autoridades públicas, especialmente para jueces, de conformidad con la jurisprudencia de la Corte Interamericana sobre Derechos Humanos.

Señala que "una lectura sistemática de la Constitución determina que las competencias atribuidas a los diversos órganos del poder público (así como a aquellos

31 Consejo de Estado, Sala de lo Contencioso Administrativo Sección Segunda-Subsección "A", sentencia de junio 24 de 2015, C.P.: Gómez Aranguren, radicado n..$^{\circ}$ 11001-03-24-000-2011-00438-00 (1245-2013).

32 Consejo de Estado, Sala de lo Contencioso Administrativo Sección Tercera-Subsección "C", sentencia de noviembre 12 de 2014, C.P.: Santofimio Gamboa, radicado n. ${ }^{\circ}$ 25000-23-26-000-2000-01335-01 (28.505). 
que son autónomos) deben ser interpretadas en clave de constitucionalización del derecho", toda vez que "los poderes públicos sólo encuentran sentido cuando ejercen sus funciones tendiendo a la realización y efectividad permanente de los principios, valores y derechos convencional y constitucionalmente establecidos". “Así, decir que una autoridad tiene la atribución para proferir o realizar determinado acto, no implica, per se, un espacio de discrecionalidad absoluta, pues el ejercicio del tal competencia no puede desconocer o socavar el principio (o los principios) que fundamentan la autoridad jurídica", en tanto se generaría y no sería admisible el abuso del derecho, el fraude a la ley y la desviación de poder, pues basta mirar el artículo $1^{\circ}$ de la Carta para apreciar que "lo que caracteriza a un Estado democrático, entre otras cosas, es la imposición de límites a las autoridades y a los gobernantes", de lo que se deprende el "principio de legalidad de las actuaciones de los funcionarios públicos", especialmente vocado a la necesidad de "motivar los actos administrativos", sustituyendo a la idea del príncipe sin límites, para lo cual cita sentencias C-010 de 2000, C-1172 de 2001 y T-204 de 2012 de la Corte Constitucional.

El Consejo de Estado precisó que la delegación "permite traspasar temporal y puntualmente ciertas atribuciones a otros funcionarios u organismos para que éstos las asuman" y "no puede ser intemporal, debe otorgarse por tiempo determinado" 33 , con lo que demuestra que las delegaciones abstractas e intemporales son, como se vio, contrarias al debido proceso.

No hay duda de que se puede delegar la investigación sobre unos determinados hechos; empero, cuando en los mismos intervienen personas aforadas, la delegación solo puede recaer en el fiscal que actué funcionalmente ante el tribunal de aforo, y sería también admisible que cuando no se tienen identificados otros aforados, la atribución funcional pueda recaer en ellos, por extensión de la delegación. Sin embargo, si en dicho contexto aparece un no aforado, sin que se hubiese contemplado la extensión de la delegación al mismo de forma motivada, es decir, delegarle para llevar a cabo investigación aparte de la otorgada, no es posible asumir que quede comprendida en el acto inicial de asignación especial, ya que, ésta carece de motivación, muy especialmente por cuanto que los fueros constitucionales y legales son refractarios a permitir el procesamiento de personas no aforadas y sobre todo en tiempos indeterminados.

En efecto, los delitos conexos se "investigarán y juzgarán" conjuntamente, dice el inciso $2^{\circ}$ del artículo 50 de la Ley 906 de 2004, esto es, sobre ellos se llevará "una sola actuación procesal", o lo que es lo mismo, una única cuerda procesal, pero la investigación del no aforado no podrá realizarse por el funcionario que conoce del

33 Consejo de Estado, Sala de lo Contencioso Administrativo Sección Quinta, sentencia de segunda instancia de abril 18 de 2013, C.P.: Yepes Barreiro radicado n. . 13001-23-31-000-2012-00010-01. 
aforado, lo cual queda fuera de sus atribuciones, de conformidad con el numeral $1^{\circ}$ del artículo 53 de la ley mencionada, en armonía con el numeral $2^{\circ}$ de su artículo 34. Pues esto solo sería posible si hubiese previsto motivada y expresamente que la delegación también recaería sobre no aforados vinculados por conexidad, así las cosas podría conocer, aunque en cuerdas procesales separadas.

Desconocer lo anterior es incurrir en violación al debido proceso con trascendencia a nulidad.

\section{VIOLACIÓN DEL DEBIDO PROCESO POR FALTA DE COMPETENCIA EN SENTIDO AMPLIO PARA REALIZAR LA INVESTIGACIÓN, LA IMPUTACIÓN Y LA FORMULACIÓN DE LA ACUSACIÓN POR PARTE DE LA FISCALÍA CUANDO SE ACTÚA FRENTE A UN NO AFORADO ESGRIMIENDO UNA DELEGACIÓN O ASIGNACIÓN ESPECIAL NO OTORGADA EXPRESA Y ESPECÍFICAMENTE PARA ELLO}

Las atribuciones legales, cualquiera que ellas sean, dependen de la ley y no de la voluntad de los servidores públicos, tal como ya se anotó, de conformidad con la Sentencia C-337 de 1993, proferida por la Corte Constitucional, que descarta la posibilidad de consagrar competencias implícitas.

Sobre las competencias o atribuciones legales en concreto de un servidor público, la Corte Constitucional ha señalado que el concepto de juez natural competente puede ser entendido en un sentido estricto y en un sentido amplio, y el quebrantamiento de las reglas que los gobiernan genera necesariamente nulidad, como se puede apreciar paladinamente en la Sentencia C-537 de 2016:

\section{LA EFECTIVIDAD DEL DERECHO AL JUEZ COMPETENTE Y LA NULIDAD POR INCOMPETENCIA}

\section{El derecho al juez natural}

16. En el Estado Social de Derecho no solo importa el qué, sino también el cómo. Igualmente, no basta con la vigencia formal de los derechos, sino su efectividad es un deber y un fin esencial del Estado (artículo 2 de la Constitución Política). El debido proceso se constituye así en una garantía particularmente relevante para la adopción de decisiones administrativas y jurisdiccionales. Una de las primeras garantías que integran el derecho fundamental al debido proceso es la de que el asunto sea juzgado por un juez competente, garantía establecida por la Revolución 
francesa ${ }^{34}$ y hoy en día prevista tanto por el artículo 29 de la Constitución Política, como por instrumentos internacionales que integran el Bloque de Constitucionalidad en sentido estricto (artículo 8 de la Convención Americana de Derechos Humanos y artículo 14 del Pacto Internacional de Derechos Civiles y Políticos). Esta garantía, vinculada con el derecho de acceso a la justicia $^{35}$, es la que se conoce como de juez natural y exige: (i) la preexistencia del juez, (ii) la determinación legal y previa de su competencia en abstracto, incluso si es una competencia especial o por fuero, y (iii) la garantía de que no será excluido del conocimiento del asunto, una vez ha asumido regularmente competencia ${ }^{36}$, aunque una modificación legal de competencia pueda significar un cambio de radicación del proceso en curso, sin que se entienda que se desconoce el derecho al juez natural, al tratarse de una " $g a$ rantía no absoluta y ponderable" ${ }^{37}$. Esta garantía orgánica e institucional busca excluir, en condiciones ordinarias, la existencia tanto de jueces ad hoc $^{38}$, "por fuera de alguna estructura jurisdiccional" 39 , como los creados ex profeso, con posterioridad al hecho ${ }^{40}$, cuyas garantías, particularmente de independencia ${ }^{41}$ e imparcialidad, puedan ser puestas en duda $^{42}$. Esto quiere

34 "El orden constitucional de las jurisdicciones no podrá ser alterado, ni los justiciables distraídos de sus jueces naturales, por ninguna comisión, ni por otras atribuciones o avocaciones distintas de aquellas determinadas por la ley": artículo 17 de la Ley francesa de los 16 y 24 de agosto de 1790 , relativa a la organización judicial.

35 Corte Constitucional, Sentencia SU-1184/01.

36 Esto implica "que una vez asignada -debidamente- competencia para conocer un caso específico, no les sea revocable el conocimiento del caso, salvo que se trate de modificaciones de competencias al interior de una institución": Corte Constitucional, Sentencia SU-1184/01.

37 Sentencia C-755/13 que declaró la constitucionalidad del Artículo 625 numeral 8 (parcial) de la Ley 1564 de 201, CGP, que dispone que para el tránsito legislativo, los procesos de responsabilidad médica en curso ante la jurisdicción ordinaria laboral, deberán ser enviados a los jueces civiles, en el estado en el que se encuentren. En esta sentencia, la Corte Constitucional reconoció que la competencia del legislador para diseñar los procesos le permite variar incluso la competencia de procesos en curso, si persigue un fin legítimo y el medio es adecuado para el mismo. Una medida parecida prevista en el art. 2 del Decreto 2001 de 2002 fue declarada exequible en la Sentencia C-1064/02.

38 Cfr. CIDH, Caso Apitz Barbera y otros ("Corte Primera de lo Contencioso Administrativo") vs. Venezuela, sentencia del 5 de agosto de 2008, Excepción Preliminar, Fondo, Reparaciones y Costas, Serie C, n. 182, párr. 50.

39 Corte Constitucional, Sentencia C-180/14.

40 En este sentido: Corte Constitucional, Sentencia C-180/14.

41 "Constituye un principio básico relativo a la independencia de la judicatura que toda persona tiene derecho a ser juzgada por tribunales de justicia ordinarios con arreglo a procedimientos legalmente establecidos": CIDH, Caso Castillo Petruzzi y otros vs. Perú, sentencia de 30 de mayo de 1999, Fondo, Reparaciones y Costas, Serie C, n. 52, párr. 129.

42 Corte Constitucional, Sentencia C- 200/02. En este sentido, "la garantía del juez natural tiene una finalidad más sustancial que formal, en razón a que su campo de protección no es solamente el claro establecimiento de la jurisdicción encargada del juzgamiento, previamente a la consideración del caso, sino también la seguridad de un juicio imparcial y con plenas garantías para las partes": Corte Constitucional, Sentencia C-328/15. 
decir que la finalidad perseguida con la garantía de que el asunto sea sometido ante un juez competente es la de evitar la arbitrariedad del Estado a través de la acción de jueces que no ofrezcan garantías y materializar el principio de igualdad, a través del deber de juzgar ante los mismos jueces, sin privilegios, ni animadversiones frente al justiciable ${ }^{43}$. Así “dicho principio opera como un instrumento necesario de la rectitud en la administración de justicia” 44. Se trata, en este sentido, de un mecanismo del Estado de Derecho que, no obstante su importancia, no garantiza por sí solo el respeto del debido proceso.

17. En cuanto al contenido mismo del derecho al juez, natural,éste pareciera permitir dos interpretaciones. Una primera, según la cual, la garantía consiste en que el asunto sea juzgado por el juez competente, es decir, que la decisión de fondo sobre el asunto planteado sea adoptada por quien recibió esta atribución del legislador. En esta interpretación, el derecho garantizado es que el juez competente profiera la sentencia "esto es, que la valoración jurídica sea llevada a cabo por quien tiene la facultad y la autoridad para hacerlo, de modo que exista un fundamento para asumir las cargas e implicaciones que de ella se derivan" 45 (negrillas no originales). Esta interpretación, adoptada en ocasiones por esta Corte ${ }^{46}$, pareciera resultar del tenor literal del artículo 29 de la Constitución Política, según el cual: "Nadie podrá ser juzgado sino conforme a leyes preexistentes al acto que se le imputa, ante juez o tribunal competente y con observancia de la plenitud de las formas propias de cada juicio" (negrillas no originales): inciso 2 del artículo 29 de la Constitución.

18. Una segunda interpretación consiste en que el derecho al juez natural implica que sea el juez competente no sólo quien decide el asunto, sino quien instruye el proceso. En este sentido, "El derecho al juez natural, es la garantía de ser juzgado por el juez legalmente competente para adelantar el trámite y adoptar la decisión de fondo respectiva" 47 (negrillas no originales). Esta segunda interpretación resulta concordante con el tenor literal de los instrumentos internacionales que integran el bloque de constitucionalidad en sentido estricto, que el demandante considera vulnerados en el caso bajo examen. Así, el numeral 1 del artículo 14 del Pacto Internacional de Derechos

43 “(...) la aplicación concreta del principio de igualdad. En virtud de este principio se garantiza a todos los justiciables el acceso a unos mismos jueces, eliminando toda suerte de privilegios o discriminaciones, y se excluye naturalmente el juzgamiento de algunas personas por jueces pertenecientes a una jurisdicción especial”: Corte Constitucional, Sentencia C-392/00.

44 C-328/15.

45 Corte Constitucional, Sentencia T-386/02.

46 “(...) garantía de toda persona a que su causa sea juzgada y definida por un juez o tribunal competente": Corte Constitucional, Sentencia C-358/15.

47 Corte Constitucional, Sentencia C-594/14. Idéntico considerando se encuentra en la Sentencia C-496/15. 
Civiles y Políticos dispone que: “1. Todas las personas son iguales ante los tribunales y cortes de justicia. Toda persona tendrá derecho a ser oída públicamente y con las debidas garantías por un tribunal competente, independiente e imparcial, establecido por la ley, en la substanciación de cualquier acusación de carácter penal formulada contra ella o para la determinación de sus derechos u obligaciones de carácter civil (...)" (negrillas no originales) y, de manera coincidente, el numeral 1 del artículo 8 de la Convención Americana de Derechos Humanos dispone que: "1. Toda persona tiene derecho a ser oída, con las debidas garantías y dentro de un plazo razonable, por un juez. o tribunal competente, independiente e imparcial, establecido con anterioridad por la ley, en la sustanciación de cualquier acusación penal formulada contra ella, o para la determinación de sus derechos y obligaciones de orden civil, laboral, fiscal o de cualquier otro carácter" (negrillas no originales).

\section{En la interpretación de esta norma, la Corte Interamericana de Derechos}

Humanos ha considerado que ser juzgado por juez incompetente implica que no se dieron los presupuestos para el debido proceso, en otras palabras, que "se está ante un procedimiento viciado desde su origen, lo cual implica que no tuvo acceso a las garantías judiciales"48. Así, consideró que se violó el derecho al juez natural porque, a más de que la ley atribuía competencia al tribunal militar, para juzgar a civiles, en primera y segunda instancia, este órgano no ofrecía las garantías de independencia exigidas ${ }^{49}$. Por consiguiente, ha considerado que cuando la justicia penal militar no resulta competente, no hay necesidad incluso de analizar si se ofrecieron suficientes garantías, a pesar de que también ha denunciado la violación al resto de garantías procesales ${ }^{50}$. Ahora bien, también ha resaltado que el derecho al juez competente debe analizarse en concreto respecto de las garantías procesales que éste ofrece ${ }^{51}$. Por esta vía, la Corte Interamericana consideró que se violaron las garantías

48 CIDH, caso Cantoral Benavides vs. Perú, sentencia del 18 de agosto de 2000, fondo, Serie C, n. 69, párr. 115.

49 CIDH, caso Castillo Petruzzi y otros vs. Perú, sentencia del 30 de mayo de 1999, Fondo, reparaciones y costas, serie c, n. 52, párr. 161 .

50 CIDH, caso Nadege Dorzema y otros vs. República Dominicana, sentencia de 24 de octubre de 2012, Fondo, Reparaciones y Costas, párr. 191.

51 "84. (...) la circunstancia de que se trate de una jurisdicción militar no significa per se que se violen los derechos humanos que la Convención garantiza a la parte acusadora. 85. De los elementos de convicción que se han rendido en este asunto, se desprende que el señor Raymond Genie Peñalba pudo intervenir en el procedimiento militar, ofrecer pruebas, ejercitar los recursos respectivos y finalmente acudir en casación ante la Corte Suprema de Justicia de Nicaragua, a la que corresponde pronunciarse sobre el fondo de la controversia criminal y determinar, en su caso, la existencia de violaciones procesales concretas. Por tanto, respecto del afectado no puede afirmarse que la aplicación de los decretos sobre enjuiciamiento militar hubiese restringido sus derechos procesales protegidos por la Convención”: CIDH, Caso Genie Lacayo vs. Nicaragua, sentencia de 29 de enero de 1997, Fondo, Reparaciones y Costas, Serie C, n. 45, párr. 84 y 85. 
judiciales porque "fue enjuiciada y condenada por un procedimiento excepcional en el que, obviamente, están sensiblemente restringidos los derechos fundamentales que integran el debido proceso" 52 . En otras decisiones ha considerado que todo el proceso está viciado per se por permitir juzgar ante un tribunal militar a civiles, ya que considera que la garantía "no se refiere únicamente al acto de juzgar, a cargo de un tribunal, sino fundamentalmente a la propia investigación" ${ }^{53}$. No obstante, no debe perderse de vista que todos los pronunciamientos de la CIDH respecto del juez natural se han referido a la materia penal, particularmente a la justicia penal militar, en la que la garantía de ser investigado y juzgado por un juez competente es especialmente relevante para que existan garantías de debido proceso.

\section{Las formas legales propias de cada juicio y el juez competente}

20. La determinación previa y abstracta del juez competente para instruir
y decidir un asunto es una competencia normativa atribuida a la Cons-
titución y a la ley ${ }^{54}$ colombianas ${ }^{55}$, para cuyo ejercicio el legislador goza de
un margen de configuración normativa amplio ${ }^{56}$, aunque limitado: a más de
los casos en los que directamente es la Constitución la que establece el juez

52 CIDH, Caso Loayza Tamayo vs. Perú, sentencia del 17 de septiembre de 1997, Fondo, serie c, n 33, párr. 62. Agrega la sentencia que "Estos procesos no alcanzan los estándares de un juicio justo ya que no se reconoce la presunción de inocencia; se prohíbe a los procesados contradecir las pruebas y ejercer el control de las mismas; se limita la facultad del defensor al impedir que éste pueda libremente comunicarse con su defendido e intervenir con pleno conocimiento en todas las etapas del proceso. El hecho de que la señora María Elena Loayza Tamayo haya sido condenada en el fuero ordinario con fundamento en pruebas supuestamente obtenidas en el procedimiento militar, no obstante ser éste incompetente, tuvo consecuencias negativas en su contra en el fuero común".

53 CIDH Caso Fernández Ortega y otros vs. México, sentencia del 30 de agosto de 2010, Excepciones preliminares, Fondo, Reparaciones y Costas, serie c n 215, párr. 177. Este considerando fue reiterado en un caso de una indagación preliminar contra militares por una agresión a un civil: CIDH, Caso Vélez Restrepo y familiares contra Colombia, sentencia del 3 de septiembre de 2012, excepciones preliminares, fondo reparaciones y costas, Serie C, n. 248, párr. 238.

54 “(...) no teniendo rango constitucional, la radicación de competencias, es del resorte ordinario del legislador regularla": Corte Constitucional, Sentencia C-208/93. “(...) siempre y cuando el constituyente no se haya ocupado de asignarla de manera explícita entre los distintos entes u órganos del Estado.”: Corte Constitucional, Sentencia C-111/00. También puede consultarse: Corte Constitucional, Sentencia C-429-01 y C-154/04.

55 La CIDH ha reconocido la competencia de la ley de cada país para determinar el juez competente: “(...) en un Estado de Derecho sólo el Poder Legislativo puede regular, a través de leyes, la competencia de los juzgadores": CIDH, caso Barreto Leiva vs. Venezuela, sentencia de 17 de noviembre de 2009, Fondo, Reparaciones y Costas, Serie C, n. 206, párr. 76.

56 “(...) mientras el legislador, no ignore, obstruya o contraríe las garantías básicas previstas por la Constitución, goza de discreción para establecer las formas propias de cada juicio" (negrillas no originales): Corte Constitucional, Sentencia C-227/09. 
natural de determinado asunto ${ }^{57}$, así como de la previsión de jurisdicciones especiales, como la indígena ${ }^{58}$, de las que el respeto de sus competencias es un imperativo constitucional, la determinación legal de la competencia debe ser una decisión razonable y proporcionada ${ }^{59}$, que implica, por ejemplo, la necesidad de razón suficiente, de especialidad, para que un asunto sea distraído de la jurisdicción ordinaria ${ }^{60}$. También existen otros límites como la prohibición de que la determinación del juez competente quede al arbitrio del juez o de las partes ${ }^{61}$, que los particulares sean juzgados por militares ${ }^{62}$ (inciso final del Artículo 213 de la Constitución) o por autoridades administrativas en materia penal, las que ni siquiera pueden instruir el sumario (inciso 3 del Artículo 116, de la Constitución), pero sí pueden actuar como ente acusador ${ }^{63}$

57 Por ejemplo, el numeral 6 del artículo 250 de la Constitución, atribuye a los jueces la adopción de las medidas para la reparación de las víctimas, a solicitud de la Fiscalía. Por esta razón fue declarado inexequible el inciso 2 del art. 24 de la Ley 1592 de 2012 al disponer que el juez remitirá el asunto a autoridades administrativas: Corte Constitucional, Sentencia C-180/14. La reciente Sentencia C-232/16 identificó las materias en las que constitucionalmente existe reserva judicial y, por lo tanto, otorgar competencia para ello, a autoridades administrativas, significaría desconocer el derecho al juez natural. Por ejemplo, la intervención, al menos posterior del juez, en la expropiación, es una exigencia constitucional (inciso $4 \mathrm{del}$ art. 58 de la Constitución Política). Cfr. Corte Constitucional, Sentencia C-229/03.

58 Según los criterios de competencia para esta jurisdicción especial, distraer al indígena de la competencia de la jurisdicción especial indígena, constituye una violación al derecho al juez natural: Corte Constitucional, Sentencia T-266/99.

59 “(...) juez natural competente con arreglo a la naturaleza de la relación jurídica y los actos jurídicos que se controvierten": Corte Constitucional, Sentencia C-1072/02 que declaró exequible el artículo 2, numeral 4 de la Ley 712 de 2001, que atribuía en bloque la competencia de litigios de seguridad social a la Jurisdicción Ordinaria Laboral y de la Seguridad Social y, por lo tanto, retiraba funciones de la Jurisdicción de lo Contencioso Administrativo.

60 Corte Constitucional C-415/02.

61 “(...) la regulación que estructura un procedimiento sin declarar cuál es la estructura jurisdiccional competente, o que deja al arbitrio de las partes su determinación, sería abiertamente inconstitucional": Corte Constitucional, Sentencia C-415/02. En el caso decidido por esta sentencia de 2002, se declaró la constitucionalidad condicionada del inciso 3 del artículo 148 de la Ley 446 de 1998 que disponía de manera antitécnica que: "Los actos que dicten las superintendencias en uso de sus facultades jurisdiccionales no tendrán acción o recurso alguno ante las autoridades judiciales. Sin embargo, la decisión por la cual las entidades se declaren incompetentes y la del fallo definitivo, serán apelables ante las mismas". La norma fue derogada por el Código General del Proceso.

62 "El traslado de competencias de la justicia común a la justicia militar y el consiguiente procesamiento de civiles por el delito de traición a la patria en este fuero, supone excluir al juez natural para el conocimiento de estas causas": CIDH, Caso Castillo Petruzzi y otros vs. Perú, sentencia de 30 de mayo de 1999, Fondo, Reparaciones y Costas, Serie C, n. 52, párr. 128.

63 "Atendiendo la naturaleza del bien jurídico y la menor lesividad de la conducta punible, el legislador podrá asignarle el ejercicio de la acción penal a la víctima o a otras autoridades distintas a la Fiscalía General de la Nación. En todo caso, la Fiscalía General de la Nación podrá actuar en forma preferente": parágrafo $2^{\circ}$ del Artículo 250 de la Constitución Política, adicionado por el Artículo 2 del Acto Legislativo 006 de 2011. 
y ser jueces competentes de otros asuntos ${ }^{64}$ y la exclusión de que violaciones de los derechos humanos sean juzgadas por la justicia penal militar ${ }^{65}$, la que no obstante es, según las circunstancias, juez natural de ciertos comportamientos ${ }^{66}$. El respeto de los fueros constitucionales también hace parte del derecho al juez natural ${ }^{67}$. Así, dentro del campo de configuración normativo determinado por estos límites, el legislador puede determinar que el "juez natural" de determinado asunto puede ser una autoridad administrativa o una autoridad judicial, tal como lo ha reconocido tanto esta Corte ${ }^{68}$, como la $\mathrm{CIDH}^{69}$. En el caso de que el juez natural sea un juez, el legislador recurre a una serie de criterios o factores de competencia, los que "(...) tienen como objetivo fundamental, definir cuál va a ser la autoridad judicial, juez o tribunal, que va a conocer, tramitar y decidir, con preferencia o exclusión de las demás, un determinado asunto que ha sido puesto en conocimiento de la administración de justicia"70.

Las características de la competencia de los jueces han sido identificadas por esta Corte de la siguiente manera:

“(i) legalidad, en cuanto debe ser definida por la ley; (ii) imperatividad, lo que significa que es de obligatoria observancia y no se puede derogar por la voluntad de las partes; (iii) inmodificabilidad, en tanto no se puede variar o cambiar en el curso del proceso (perpetuatio jurisdictionis); (iv) indelegabilidad, ya que no puede ser cedida o delegada por la autoridad que la detenta legalmente; $y(v)$ es de orden público, en razón a que se sustenta o

64 Por no cumplir con el carácter excepcional y preciso de las funciones jurisdiccionales de la administración, la Sentencia C-156/13 declaró inexequibles las funciones jurisdiccionales atribuidas al Ministerio de Justicia y del Derecho.

65 CIDH, Caso Radilla Pacheco vs. México, sentencia de 23 de noviembre de 2009, Excepciones preliminares, Fondo, reparaciones y costas, Serie C, n. 209, párr. 273; CIDH Caso Fernández Ortega y otros. vs. México, sentencia de 30 de agosto de 2010, Excepciones prelimitares, Fondo, reparaciones y costas, Serie C n. 215, párr 176; CIDH, caso Cabrera García y Montiel Flores vs. México, sentencia de 26 de noviembre de 2010, Excepción Preliminar, Fondo, Reparaciones y Costas, Serie C, n. 220, párr. 198.

66 La justicia penal militar “(...) constituye una excepción al principio del juez natural ordinario, a partir de las diferencias existentes entre los deberes y las responsabilidades que tienen los ciudadanos y las que constitucionalmente deben asumir los integrantes de la Fuerza Pública”: Corte Constitucional, Sentencia C-338/16. Este considerando se inspira de la Sentencia C-084/16.

67 Por ejemplo, respecto del juzgamiento del Presidente de la República: artículos 178 y 199 de la Constitución Política.

68 Por ejemplo, respecto de las funciones disciplinarias del Procurador General de la Nación, autoridad administrativa, como juez natural en materia disciplinaria: Corte Constitucional, Sentencia C-429/01.

69 CIDH, Caso Yatama vs. Nicaragua, sentencia de 23 de junio de 2005, Excepciones Preliminares, Fondo, Reparaciones y Costas, Serie C, n. 127, párr. 149.

70 Corte Constitucional, Sentencia C-328/15. 
fundamenta en principios y criterios que se relacionan con la prevalencia del interés general"71 (negrillas originales).

21. Esta garantía de juez natural no puede desligarse de la del derecho a que se cumplan las formas propias de cada juicio, es decir, los términos, trámites, requisitos, etapas o formalidades establecidas por el legislador, de acuerdo con los numerales 1 y 2 del artículo 150 de la Constitución Política, para la adopción de una decisión por parte del juez competente ${ }^{72}$. Se trata de otra expresión del principio de juridicidad propio de un Estado de Derecho en el que los órganos del poder público deben estar sometidos al ordenamiento jurídico, no sólo en la función (competencia), sino en el trámite (procedimiento) para el ejercicio de dicha función. Ambos elementos hacen, determinados el uno por el otro, que se desarrolle un debido proceso. Es justamente en la determinación de las consecuencias procesales del trámite de la actuación procesal, por parte de un juez incompetente, en donde se pone en evidencia el carácter inescindible del juez natural y las formas propias de cada juicio ${ }^{73}$ (resaltado fuera de texto).

Se destaca en la Sentencia C-537 de 2016, como decálogo del debido proceso constitucional que

1) El debido proceso se constituye en una garantía particularmente relevante para la adopción de decisiones administrativas y jurisdiccionales, según los artículos 29 y 228 constitucionales;

2) El juez natural es una garantía vinculada con el derecho de acceso a la justicia de que da cuenta el artículo 229 de la Carta Política;

3) Se trata de una garantía orgánica e institucional que busca excluir, en condiciones ordinarias, la existencia de jueces ad hoc, en tanto pretende evitar la arbitrariedad del Estado y materializar el principio de igualdad, por lo que se constituye en un instrumento necesario de la rectitud en la administración de justicia;

4) El juez natural puede entenderse en sentido estricto, como lo hace la Carta Política, o en sentido amplio, como se desprende de los Tratados Internacionales sobre Derechos Humanos;

71 Corte Constitucional, Sentencia C-328/15.

72 Corte Constitucional, sentencias C-562/97 y C-383/05.

73 Corte Constitucional Sentencia C-537 de 2016. Fundamentos Jurídicos n. ${ }^{\text {s }} 16,17,18,19,20$ y 21. 
5) La Corte Interamericana de Derechos Humanos ha considerado que ser juzgado por juez incompetente, en cualquiera de los sentidos mencionados, implica que no se dieron los presupuestos para el debido proceso, en otras palabras, que se está ante un procedimiento viciado desde su origen, lo cual implica que no se tuvo acceso a las garantías judiciales;

6) Concepto en el que se incluye, por supuesto, la facultad para instruir y decidir un asunto como competencia normativa atribuida por la Constitución y la ley a un servidor público;

7) De allí la existencia de la prohibición que la determinación del juez competente quede al arbitrio del juez o de las partes;

8) La garantía de juez natural no puede desligarse de la del derecho a que se cumplan las formas propias de cada juicio, es decir, los términos, trámites, requisitos, etapas o formalidades establecidas por el legislador;

9) Se trata de otra expresión del principio de juridicidad propio de un Estado de Derecho en el que los órganos del poder público deben estar sometidos al ordenamiento jurídico, no solo en la función (competencia), sino en el trámite (procedimiento) para el ejercicio de dicha función. Ambos elementos hacen, determinados el uno por el otro, que se desarrolle un debido proceso; y,

10) Es justamente en la determinación de las consecuencias procesales del trámite de la actuación procesal, por parte de un juez incompetente, en donde se pone en evidencia el carácter inescindible del juez natural y las formas propias de cada juicio.

La sentencia antes referida es de significativa importancia, pues señala que la competencia "como vinculación positiva y como vinculación negativa" para efectos de validez de las decisiones que se adoptan en un Estado de Derecho, es asunto definitorio del cumplimiento del debido proceso (Fundamento Jurídico No 22), esto es, determina lo que debe conocer - positiva- y por supuesto lo que no debe conocer -negativa- un funcionario judicial, aspecto especialmente relevante, puesto que, de conformidad con el artículo 16 del Código General del Proceso y la jurisprudencia constitucional, la violación del juez natural, en sentido estricto o en sentido amplio, cuando se da por razones de los factores de competencia funcional y subjetivo, dan origen a una nulidad insaneable (Fundamentos Jurídicos n. ${ }^{\text {os }} 23$ y 24).

Esta norma es aplicable al proceso penal por virtud de lo dispuesto en el artículo 1 del Código General del Proceso, pero muy especialmente por cuanto, en este cuerpo sistemático procesal con pretensiones generales, se desarrolla el debido proceso constitucional y se consigna la validez de la Teoría General del Proceso, esto es, la ciencia del Derecho procesal, en los términos de sus artículos 11 y 12. 
Las competencias del Fiscal General, el Vicefiscal General y los fiscales delegados por razón territorial son amplias, no circunscritas ni a distritos judiciales ni a circuitos judiciales, ni a municipios, de conformidad con lo dispuesto en el Artículo 3 de la Ley 938 de 2004. No obstante, para efectos diferentes a dicho factor de atribución de funciones, debe actuarse a través del respectivo fiscal delegado, como se desprende del Artículo 2 ibídem. La denominación de unidades nacionales y seccionales es operativa para efectos territoriales; sin embargo, de todos modos los otros factores determinantes del conocimiento deben ser respetados, de tal manera que a partir de los artículos 4 y 5 ibídem, se entiende que al interior de las unidades debe respetarse la nomenclatura que para cada fiscal delegado se ha configurado en la planta de personal por el artículo Transitorio 1 de la Ley 938 de 2004, aún vigente, es decir, los fiscales locales no podrían conocer de hechos atribuidos a los fiscales delegados ante los jueces de circuito y los fiscales seccionales no podrían conocer de hechos por los cuales deban conocer los fiscales delegados ante los tribunales superiores de distrito judicial, tampoco un fiscal ante tribunal superior de distrito judicial podría conocer de hechos de los que deban conocer los fiscales delegados ante la Corte Suprema de Justicia, incluso tal prohibición abarca a la delegación o asignación especiales, aunque, por virtud de éstas, si podría conocerse en competencia vertical de arriba hacia abajo, cuando no se afecte el fuero constitucional o legal.

También así opera la actual regulación orgánica de la Fiscalía General de la Nación, toda vez que, de conformidad con los artículos 250 de la Carta Política y 4 del Decreto 016 de 2014, el Fiscal ejerce sus funciones de investigación y acusación directamente o a través de sus fiscales delegados, lo que ratifican los artículos 17 numeral $1^{\circ}, 20$ numeral $1^{\circ}, 29$ numeral $3^{\circ}, 31$ numeral $3^{\circ}$ y 33 numeral $1^{\circ}$, con refrendación inequívoca por el Artículo 49 ibídem.

Pues bien, en sentido negativo, un funcionario judicial por ejemplo, un Fiscal Delegado ante Tribunal de Distrito, según el artículo Transitorio 1 de la Ley 938 de 2004 - que sólo conocen de procesos contra servidores públicos aforados, ante la primera instancia tramitada en los Tribunales Superiores de Distrito, ostentan una competencia fundada funcional y subjetivamente, o sea, no dependiente de la naturaleza del asunto-, no podría conocer de asuntos por fuera del factor subjetivo, aunque sí territorialmente por fuera de su jurisdicción, toda vez que se ha previsto que el desconocimiento de dicho factor no es determinante para el ejercicio de la función judicial de la Fiscalía General de la Nación, de conformidad con los artículos 45 de la Ley 906 de 2004, 3 de la Ley 938 de 2004 y 49 del Decreto 016 de 2014, normas que, de manera expresa, establecen el concepto de "competencia" para la Fiscalía General de la Nación.

Solo cuando se le delegue o designe como funcionario especial puede asumir competencias por fuera de los factores funcional y subjetivo originarios de su competencia en sentido amplio, pues no se cumple con los requisitos del punto $n .^{\circ} 2$ antes señalado, como tampoco podría hacerlo por virtud de conexidad, pues tal factor competencial 
no tiene aplicación cuando se trata de fuero constitucional o legal. Esto decir, los delitos conexos se "investigarán y juzgarán" conjuntamente, dice el inciso $2^{\circ}$ del artículo 50 de la Ley 906 de 2004, esto es, sobre ello se llevará "una sola actuación procesal", o lo que es lo mismo, una única cuerda procesal, pero la investigación no podrá realizarse por dicho funcionario que conoce del aforado, respecto de un no aforado, lo cual queda fuera de sus atribuciones, de conformidad con el numeral $1^{\circ}$ del artículo 53 de la ley mencionada, en armonía con el numeral $2^{\circ}$ de su artículo 34. Sólo si se hubiere previsto motivada y expresamente que la delegación también recae sobre no aforados vinculados por conexidad podría conocer, aunque en cuerdas procesales separadas.

Asumir competencia de un proceso en el que no juegan los factores funcionales y subjetivos de competencia, cuando se trata de un particular no sujeto a cargo o función pública, es irregularidad que trasciende a nulidad insaneable por virtud del concepto negativo de la competencia, según el Fundamento Jurídico n. ${ }^{\circ} 22$ de la Sentencia C-537 de 2016.

\section{VIOLACIÓN DEL DEBIDO PROCESO RESPECTO} DE LA ACTUACIÓN DEL FISCAL DELEGADO O ASIGNADO
ESPECIALMENTE, POR FALTA DE NOTIFICACIÓN DEL ACTO
ADMINISTRATIVO QUE PRETENDIÓ VARIAR LA COMPETENCIA
DEL JUEZ NATURAL EN SENTIDO AMPLIO, POR HACERSE
EL ACTO ADMINISTRATIVO INEJECUTABLE E INEFICAZ

En cuanto a la publicidad del acto administrativo que finaliza el trámite administrativo de asignación o delegación de funcionario especial por la Fiscalía General de la Nación, en el ámbito del Artículo 209 de la Carta Política, se aplican las jurisprudencias constitucionales que tienen dicho que "la notificación es una condición de posibilidad de la ejecución del debido proceso"74; esto es, por tener como fundamento nuclear el respeto por el debido proceso, se trata de "un acto reglado, es decir sujeto al principio de legalidad" 75 . De allí que categóricamente haya de afirmarse que "el conocimiento de la providencia debe entenderse producido cuando se han observado todas las formalidades prescritas por la ley para llevar a cabo la notificación"76. El Consejo de Estado tiene dicho que la firmeza de un acto solo se produce cuando se notifica, de allí que "la firmeza o eficacia del acto administrativo... hace que sea inoponible a los administrados" 77 , esto es, "de conformidad con el artículo 87 del CPACA, quedan en firme los actos administrativos y se entiende concluida la

74 Corte Constitucional, Sentencia T-419 de 1994.

75 Ídem, Sentencia C-648 de 2001.

76 Ídem, Sentencia C-648 de 2001.

77 Consejo de Estado, Sala de lo Contencioso Administrativa Sección Primera, sentencia de septiembre 24 de 2015, C.P.: Vargas Ayala, radicado n. ${ }^{\circ}$ 05001-23-33-000-2014-00708-01. 
actuación administrativa en los siguientes eventos: (i) cuando no proceda recurso alguno contra el acto, desde el día siguiente a la notificación, comunicación o publicación; (ii) cuando se interpongan los recursos procedentes, desde el día siguiente a la notificación, comunicación o publicación de la resolución que los decida; (iii) si los recursos no se interponen o se renuncia expresamente a ellos, desde el día siguiente al del vencimiento del término para interponerlos; (iv) cuando se desista de los recursos, desde el día siguiente al de la notificación de la aceptación del tal desistimiento y $(\mathrm{v})$ cuando se protocolice el silencio administrativo positivo [art. 85 CPACA], desde el día siguiente" 78 , puesto que de la debida notificación surge la ejecutividad y ejecutoriedad:

La firmeza del acto únicamente significa que adquiere dos de sus principales características: ejecutividad, es decir que es obligatorio; y ejecutoriedad, que habilita a la administración para que de forma directa proceda a su cumplimiento ${ }^{79}$.

Esto es,

En la notificación personal, conforme lo expresa el artículo 44 del Código Contencioso Administrativo, se debe entregar al interesado, copia íntegra, auténtica y legible del acto administrativo. Ahora, en caso tal de no realizarse la notificación personal del acto administrativo al cabo de los cinco días del envío de la citación de que trata la norma, la misma debe hacerse mediante edicto fijado en un lugar público por el término de diez (10) días conforme lo indica el artículo 45 del CCA. La notificación del acto administrativo se constituye entonces, en una obligación para la administración y en un presupuesto necesario de eficacia y oponibilidad del acto frente a su destinatario. La falta o la irregularidad de la misma genera como consecuencia que el acto administrativo sea ineficaz, esto es, que no produzca los efectos para los cuales se profirió, en consideración a que la publicidad del acto administrativo es un requisito indispensable para que las decisiones administrativas sean obligatorias ${ }^{80}$.

Por supuesto que cuando se produce un acto administrativo de designación de funcionario especial este existe, pero no adquiere firmeza como se ha venido sosteniendo, ya que "debe recordarse que la existencia del acto es distinta a su oponibilidad, pues,

78 Consejo de Estado, Sala de lo Contencioso Administrativa Sección Cuarta, sentencia de octubre 7 de 2016, C.P.: Martha Briceño, radicado n. ${ }^{\circ}$ 11001-03-24-000-2014-00389-00(21286)

79 Consejo de Estado, Sala de lo Contencioso Administrativa Sección Cuarta, sentencia de marzo 17 de 2016, C.P.: Ramírez Ramírez, radicado n. ${ }^{\circ}$ 05001-23-31-000-2014-00784-01(22122).

80 Consejo de Estado, Sala de lo Contencioso Administrativa Sección Segunda Subsección “A”, sentencia de mayo 5 de 2016, C.P.: Hernández Gómez, radicado n. . 08001-23-31-000-2004-02561-02(0063-13). 
mientras la primera atañe a su formación, la segunda consiste en el momento a partir del cual éste produce efectos" 81 . En fin, "debe recordarse que la falta de notificación de un acto administrativo no lo torna en ilegal, sino que lo hace inoponible e ineficaz frente a quien(es) lo desconoce(n). Así lo puso de presente esta Sección en sentencias de 23 de agosto de 2012 y 14 de mayo de 2015, cuando manifestó: ... la falta de notificación no atenta contra la validez del acto administrativo sino que afecta su eficacia' y la no notificación del acto es un factor extrínseco que sólo puede generar la no producción de efectos jurídicos" $" 82$.

El funcionario que actué de esta manera lo hace ilegalmente, puesto que sin firmeza del acto administrativo, da paso a la ejecución del mismo, lo cual es contrario a Derecho, pues se tiene dicho que "cuando se ejecuta de manera anticipada un acto administrativo, lo cual bien puede ocurrir cuando la decisión que en él se contiene no se notifica en debida forma, o simplemente se omite por completo su adecuada publicidad, o cuando la ejecución se lleva a cabo antes de cobrar firmeza, todo lo cual puede dar lugar a la configuración de un daño antijurídico"83.

Quiere decir lo anterior que no resulta posible ejecutar las decisiones judiciales sin plena notificación. De allí que la Corte Constitucional tenga dicho que sin el lleno de los requisitos legales, "la notificación se entenderá por no hecha, y no producirá efectos legales" 84 (resaltado fuera del texto).

La evolución jurisprudencial ha solidificado un precedente judicial de obligatorio cumplimiento $^{85}$, que en lo fundamental se traduce en los siguientes conceptos vigentes en materia constitucional:

... a). El principio de publicidad se ha estructurado como un elemento trascendental del Estado Social de Derecho y de los regímenes democráticos, ya que mediante el conocimiento de las actuaciones judiciales y administrativas, y de las razones de hecho y de derecho que les sirven de fundamento, se garantiza la imparcialidad y la transparencia de las decisiones adoptadas por las autoridades, alejándose de cualquier actuación oculta o arbitraria contraria a los principios, mandatos y reglas que gobiernan la función pública (...) El principio de publicidad persigue el logro de una finalidad de interés público.

81 Consejo de Estado, Sala de lo Contencioso Administrativa Sección Quinta, sentencia de marzo 9 de 2017, C.P.: Bermúdez Bermúdez, radicado n. 11001-03-28-000-2017-00007-00.

82 Consejo de Estado, Sala de lo Contencioso Administrativa Sección Primera, sentencia de noviembre 3 de 2016, C.P.: Serrato Valdez, radicado n. ${ }^{\circ}$ 13001-23-31-000-2001-02023-01.

83 Consejo de Estado, Sala de lo Contencioso Administrativa Sección Tercera Subsección "A", sentencia de noviembre 12 de 2014, C.P.: Andrade Rincón, radicado n. ${ }^{\circ}$ 25000-23-26-000-2003-0032701(29923).

84 Corte Constitucional, Sentencia T-215 de 2005.

85 Ídem, sentencias C-836 de 2001 y C-335 de 2008. 
Ello, porque la publicidad, como principio, no es una mera norma susceptible de aplicarse o no en un determinado caso, sino que por su fuerza normativa y su textura abierta está llamado a tener eficacia directa por sí mismo en la diversidad de actuaciones administrativas o judiciales, salvo que a través de un juicio de ponderación constitucional resulte inaplicable a un asunto en concreto. De allí que, por regla general, toda actuación o proceso judicial debe ser público (...) El principio de publicidad conduce al logro de la obediencia jurídica en un Estado democrático de derecho, ya que solo en la medida en que las personas tienen conocimiento de las actuaciones judiciales, esto es, del principio, regla o razón jurídica que constituye la base de una decisión judicial, las partes o los interesados podrían apelar a dicho fundamento para ajustar su conducta a las decisiones de los jueces. En este orden de ideas, es preciso recordar que así como la imperatividad y obligatoriedad de la ley presupone su conocimiento por parte de los ciudadanos mediante su publicación en el Diario Oficial, también la imperatividad y obligatoriedad de las sentencias judiciales suponen su publicidad, pues lógicamente aquello que es desconocido por las partes o terceros no puede ser objeto de imposición, so pena de alterar y desconocer los valores, principios y reglas de un Estado Social Derecho. Sin embargo, es preciso aclarar que en cada caso la publicidad debe adecuarse a los sistemas de comunicación previstos en la ley...

b). En torno a las providencias judiciales, es posible igualmente distinguir entre los conceptos de ejecutoriedad de las decisiones judiciales (es decir, fallos en firme susceptibles de ser voluntaria o forzosamente ejecutados) y la producción de sus efectos jurídicos. Un fallo judicial no puede resultar obligatorio para los sujetos procesales cuando éstos no tienen conocimiento de su contenido, ya que los efectos jurídicos derivados de su obligatoriedad suponen el previo conocimiento de dichos sujetos procesales (...) La expresión notificar, en el campo del derecho, significa 'hacer saber' o 'hacer conocer'. Por ello, la notificación más que pretender formalizar la comunicación del inicio, desarrollo o agotamiento de una actuación, procura asegurar la legalidad de las determinaciones adoptadas en una instancia judicial, ya que al 'hacer conocer' se garantiza que los distintos sujetos procesales puedan utilizar los instrumentos o medios judiciales necesarios para la protección de sus intereses (...) Una actuación judicial que no haya sido previamente notificada, no sólo desconoce el principio de publicidad sino también el derecho de defensa y de contradicción, lo que conlleva a la ineficacia de la decisión adoptada por el juez (...) La notificación como desarrollo específico del principio de publicidad, busca no sólo garantizar la efectividad del derecho fundamental al debido proceso sino alcanzar el logro de propósitos constitucionales más amplios. En consecuencia, si la notificación de las providencias no tiene como única finalidad que los sujetos procesales interpongan recursos, entonces no existe ninguna razón válida para considerar que una providencia ejecutoriada no deba ser notificada, más cuando a partir de su conocimiento surge la obligación 
para los sujetos procesales de adecuar voluntaria o coactivamente sus actos a lo ordenado por la autoridad judicial. Sin embargo, la Corte precisa que no se trata de imponer la obligación de notificar todo tipo de providencias, sino más bien de resaltar, que la firmeza de una providencia (entre ellas, las sentencias, los autos interlocutorios o las resoluciones), por el hecho de carecer de recursos o haberse resuelto los legalmente procedentes, no constituye un motivo o una razón suficiente para excluirlas de notificación, puesto que el principio de publicidad y la institución jurídica de la notificación cumplen propósitos constitucionales de mayor relevancia (...) La ejecutoria de una decisión judicial es un fenómeno distinto al instituto procesal de la cosa juzgada, ya que éste último tiene como objetivo otorgar una calificación jurídica especial a algunas decisiones ejecutoriadas. Por lo cual, se puede afirmar que no existe cosa juzgada sin ejecutoria, pero no siempre la ejecutoria de una providencia judicial entraña la existencia de aquélla (es lo que ocurre con los autos interlocutorios)... Solamente cuando las decisiones judiciales quedan ejecutoriadas son de estricto cumplimiento, sin embargo, la producción de sus efectos jurídicos supone el conocimiento previo de los sujetos procesales (...) Una decisión judicial resulta obligatoria e imperativa porque se encuentra plenamente ejecutoriada, mas la producción de sus efectos jurídicos depende de la previa notificación de su contenido a los distintos sujetos procesales. Esto porque si una de las finalidades de la publicidad consiste en informar a dichos sujetos sobre la obligación de acatar una determinada conducta, no se podría obtener su cumplimiento coactivo en contra de la voluntad de los obligados, cuando éstos ignoran por completo lo dispuesto en la decisión judicial, desconociendo la premisa fundamental de un régimen democrático, según la cual el conocimiento de una decisión permite establecer los deberes de las personas y demarcar el poder de coacción de las autoridades, lejos de medidas arbitrarias o secretas propias de regímenes absolutistas" 86 (resaltado fuera del texto).

Por ello se ha dicho que, al no observarse el anterior precedente judicial, "es dable afirmar que incurre en vía de hecho la autoridad judicial o administrativa que le hace producir efectos a una providencia judicial que no ha sido notificada al afectado, acorde con las previsiones prescritas en el ordenamiento, así contra la decisión no proceda ningún recurso" 87 .

El Consejo de Estado, siguiendo muy de cerca la jurisprudencia constitucional, ha precisado que la expedición de un acto administrativo "sin la observancia de lo previsto en el Código Contencioso Administrativo en lo relativo al agotamiento de

86 Ídem, Sentencia C-641 de 2002. Ratificada, para la materia disciplinaria, por la Sentencia C-1076 de 2002 .

87 Ídem, Sentencia T-1137 de 2004. 
la vía gubernativa y firmeza de los actos, constituye una vía de hecho por defecto material por desconocimiento del debido proceso" $" 88$.

\section{CONCLUSIONES}

1) Prescindir de la formación y trámite obligatorio por parte de la administración, incluida la Fiscalía General de la Nación, cuando se inicia una actuación administrativa a instancia de parte u oficiosamente, comporta violación al debido proceso. Ello comporta, necesariamente, nulidad de la actuación procesal.

2) Si no se notifica el acto que inicia la actuación administrativa ni el que la concluye, la consecuencia no puede ser otra que la violación al debido proceso, lo cual resulta evidente y así debe ser declarada, toda vez que, además, se desatiende el mandato según el cual está prohibido especialmente a las autoridades "ejecutar un acto que no se encuentre en firme" (numeral 11 del artículo 9 de la Ley 1137 de 2011), puesto que por el contrario, el deber funcional de los servidores públicos es facilitar las notificaciones (numeral 15 del artículo 9 ibídem). Nulidades por violación al debido proceso y al derecho de defensa son incuestionables ante las referidas irregularidades procedimentales.

3) Si no se cumple en las asignaciones y delegaciones especiales con el debido proceso de motivar de manera concreta y específica las razones que fundan, por demás acreditadas de manera suficiente, el hecho de relevar a un juez natural en sentido amplio de sus atribuciones constitucionales y legales, se incurre en violación al debido proceso por desconocimiento de las garantías constitucionales del debido proceso, consecuentemente en nulidad procesal.

4) Y finalmente, si se desconocen, como consecuencia de lo anterior, la vinculación negativa de un funcionario judicial, cuya competencia natural deriva de los factores funcionales y subjetivos, asumiendo competencia por la naturaleza del asunto sin una debida delegación o asignación especial, se incurre en una nulidad de carácter insaneable a la luz de la jurisprudencia de la Corte Constitucional y del artículo 16 del Código General del Proceso, aplicable al proceso penal según sus artículos 1, 11 y 12, y muy especialmente, por lo establecido por la jurisprudencia constitucional en Sentencia C-537 de 2016.

88 Consejo de Estado, Sala de lo Contencioso Administrativo Sección Segunda Subsección "B”, sentencia de mayo 7 de 2013, C.P.: Ramírez De Páez, radicado n. ${ }^{\circ}$ 11001-03-25-000-2010-00042-00. 


\section{BIBLIOGRAFÍA}

Asamblea Nacional Constituyente, Comisión Primera, sesión de abril 15 de 1991.

Consejo de Estado, Sala de lo Contencioso Administrativa Sección Cuarta, sentencia de marzo 5 de 2015, C.P. Bastidas Bárcenas, radicado n. . 25000-23-27-0002010-00208-01(19382).

Consejo de Estado, Sala de lo Contencioso Administrativa Sección Primera, sentencia de septiembre 24 de 2015, C.P. Vargas Ayala, radicado n..$^{\circ}$ 05001-23-33-0002014-00708-01.

Consejo de Estado, Sala de lo Contencioso Administrativa Sección Cuarta, sentencia de octubre 7 de 2016, C.P. Martha Briceño, radicado n. $.^{\circ} 11001-03-24-000-$ 2014-00389-00(21286)

Consejo de Estado, Sala de lo Contencioso Administrativa Sección Cuarta, sentencia de marzo 17 de 2016, C.P. Ramírez Ramírez, radicado n. ${ }^{\circ}$ 05001-23-31-0002014-00784-01(22122).

Consejo de Estado, Sala de lo Contencioso Administrativa Sección Segunda Subsección "A", sentencia de mayo 5 de 2016, C.P. Hernández Gómez, radicado n. ${ }^{\circ}$ 08001-23-31-000-2004-02561-02(0063-13).

Consejo de Estado, Sala de lo Contencioso Administrativa Sección Quinta, sentencia de marzo 9 de 2017, C.P. Bermúdez Bermúdez, radicado n. 11001-03-28000-2017-00007-00.

Consejo de Estado, Sala de lo Contencioso Administrativa Sección Primera, sentencia de noviembre 3 de 2016, C.P. Serrato Valdez, radicado n. . 13001-23-31-0002001-02023-01.

Consejo de Estado, Sala de lo Contencioso Administrativa Sección Tercera Subsección "A", sentencia de noviembre 12 de 2014,C.P. Andrade Rincón, radicado n. ${ }^{\circ}$ 25000-23-26-000-2003-00327-01(29923).

Consejo de Estado, Sala de lo Contencioso Administrativo Sección SegundaSubsección “A”, sentencia de junio 24 de 2015, C.P. Gómez Aranguren radicado n. ${ }^{\circ}$ 11001-03-24-000-2011-00438-00 (1245-2013).

Consejo de Estado, Sala de lo Contencioso Administrativo Sección Quinta, sentencia de segunda instancia de septiembre 1 de 2016, C.P. Bermúdez Bermúdez, radicado n. ${ }^{\text { }}$ 70001-23-33-000-2015-00516-01. 
Consejo de Estado, Sala de lo Contencioso Administrativo Sección Primera, sentencia de noviembre 23 de 1993, C.P. Ariza Muñoz, radicación n. ${ }^{\circ} 2284$.

Consejo de Estado, Sala de lo Contencioso Administrativo Sección SegundaSubsección “A”, sentencia de junio 24 de 2015, C.P. Gómez Aranguren, radicado n. ${ }^{\circ} 11001-03-24-000-2011-00438-00$ (1245-2013).

Consejo de Estado, Sala de lo Contencioso Administrativo Sección Tercera-Subsección "C", sentencia de noviembre 12 de 2014, C.P. Santofimio Gamboa, radicado n. ${ }^{\circ}$ 25000-23-26-000-2000-01335-01 (28.505).

Consejo de Estado, Sala de lo Contencioso Administrativo Sección Quinta, sentencia de segunda instancia de abril 18 de 2013, C.P. Yepes Barreiro radicado n. ${ }^{\circ}$ 13001-23-31-000-2012-00010-01.

Consejo de Estado, Sala de lo Contencioso Administrativo Sección Segunda Subsección “B”, sentencia de mayo 7 de 2013, C.P. Ramírez de Páez, radicado n. 11001-03-25-000-2010-00042-00.

Consejo de Estado, Sala de lo Contencioso Administrativo, Sección Segunda Subsección “A”, sentencia de agosto 12 de 2009, C.P. Vergara Quintero, radicación n. 25000-23-25-000-1999-07269-01(4334-05).

Consejo de Estado, Sala de lo Contencioso Administrativo, sentencia de mayo 30 de 2000, C.P. Rodríguez Villamizar, radicación n. ${ }^{\circ}$ AC-9877.

Consejo de Estado, Sala Plena de lo Contencioso Administrativo, auto de agosto 2 de 2011, radicado n. ${ }^{\circ} 11001031500020100073700$.

Constitución política de Colombia [Const.] (1991) Artículo 178 [Título vi]. 2a ed. Legis.

Constitución política de Colombia [Const.] (1991) Artículo 199 [Título viI]. 2a ed. Legis.

Constitución política de Colombia [Const.] (1991) Artículo 250 [Título ViI]. 2a ed. Legis.

Corte Constitucional, (19 de marzo) sentencia C- 200 de 2002. [M.P.: Álvaro Tafur Galvis]

Corte Constitucional, (25 de enero) sentencia C-036 de 2005, M.P.: Humberto Sierra Porto. 
Corte Constitucional, (3 de diciembre) sentencia C-1072 de 2002, M.P.: Eduardo Montealegre Lynett.

Corte Constitucional, (9 de febrero) sentencia C-111 de 2000, M.P.: Álvaro Tafur Galvis.

Corte Constitucional, (24 de febrero) sentencia C-154 de 2004, M.P.: Álvaro Tafur Galvis.

Corte Constitucional, (20 de marzo) sentencia C-156 de 2013, M.P.: Luis Ernesto Vargas Silva.

Corte Constitucional, (27 de marzo) sentencia C-180 de 2014, M.P.: Alberto Rojas Ríos.

Corte Constitucional, (3 de junio) sentencia C-208 de 1993, M.P.: Hernando Herrera Vergara.

Corte Constitucional, (30 de marzo) sentencia C-227 de 2009, M.P.: Luis Ernesto Vargas Silva.

Corte Constitucional, (18 de marzo) sentencia C-229 de 2003, M.P.: Rodrigo Vargas Gil.

Corte Constitucional, (27 de mayo) sentencia C-328 de 2015, M.P.: Luis Guillermo Guerrero Pérez.

Corte Constitucional, (16 de abril) sentencia C-335 de 2008, M.P.: Humberto Sierra Porto.

Corte Constitucional, (19 de agosto) sentencia C-337 de 1993, M.P.: Vladimiro Naranjo Mesa.

Corte Constitucional, (29 de junio) sentencia C-338 de 2016, M.P.: Luis Ernesto Vargas Silva.

Corte Constitucional, (15 de mayo) sentencia C-372 de 2002, M.P.: Jaime Córdoba Triviño.

Corte Constitucional, (12 de abril) sentencia C-383 de 2005, M.P.: Álvaro Tafur Galvis.

Corte Constitucional, (6 de abril) sentencia C-392 de 2000, M.P.: Antonio Barrera Carbonell. 
Corte Constitucional, (28 de mayo) sentencia C-415 de 2002, M.P.: Eduardo Montealegre Lynett.

Corte Constitucional, (2 de mayo) sentencia C-429 de 2001, M.P.: Jaime Araújo Rentería.

Corte Constitucional, (4 de abril) sentencia C-537 de 2016, M.P.: Alejandro Linares Cantillo.

Corte Constitucional, (20 de agosto) sentencia C-594 de 2014, M.P.: Jorge Ignacio Pretelt Chaljub.

Corte Constitucional, (13 de agosto) sentencia C-641 de 2002, M.P.: Rodrigo Escobar Gil.

Corte Constitucional, (20 de junio) sentencia C-648 de 2001, M.P.: Marco Gerardo Monrroy Cabra.

Corte Constitucional, (8 de julio) sentencia C-662 de 2004, M.P.: Rodrigo Uprimny Yepes.

Corte Constitucional, (26 de abril) sentencia C-755 de 2013, M.P.: María Victoria Calle Correa.

Corte Constitucional, (9 de agosto) sentencia C-836 de 2001, M.P.: Rodrigo Escobar Gil.

Corte Constitucional, (6 de noviembre) sentencia C-948 de 2002, M.P.: Álvaro Tafur Galvis.

Corte Constitucional, (26 de septiembre) sentencia C-985 de 2005, M.P.: Alfredo Beltrán Sierra.

Corte Constitucional, (13 de noviembre) sentencia SU-1184 de 2001, M.P.: Eduardo Montealegre Lynett.

Corte Constitucional, (25 de enero) sentencia T-024 de 1996, M.P.: Alejandro Martínez Caballero.

Corte Constitucional, (17 de febrero) sentencia T-073 de 1997, M.P.: Vladimiro Naranjo Mesa.

Corte Constitucional, (10 de marzo) sentencia T-1137 de 2004, M.P.: Álvaro Tafur Galvis. 
Corte Constitucional, (12 de febrero) sentencia T-116 de 2004, M.P.: Eduardo Montealegre Lynett.

Corte Constitucional, (10 de marzo) sentencia T-215 de 2005, M.P.: Humberto Sierra Porto.

Corte Constitucional, (3 de abril) sentencia T-264 de 2009, M.P.: Luis Ernesto Vargas Silva.

Corte Constitucional, (27 de abril) sentencia T-266 de 1999, M.P.: Carlos Gaviria Díaz.

Corte Constitucional, (10 de mayo) sentencia T-323 de 1999, M.P.: José Gregorio Hernández Galindo.

Corte Constitucional, (10 de mayo) sentencia T-386 de 2002, M.P.: Rodrigo Escobar Gil.

Corte Constitucional, (23 de septiembre) sentencia T-419 de 1994, M.P.: Eduardo Cifuentes Muñoz.

Corte Constitucional, (19 de mayo) sentencia T-429 de 2011, M.P.: Jorge Ignacio Pretelt Chaljub.

Corte Constitucional, (28 de agosto) sentencia T-599 de 2009, M.P.: Juan Carlos Henao Pérez.

Corte Constitucional, (3 de agosto) sentencia T-950 de 2011, M.P.: Jorge Iván Palacio Palacio.

Corte Constitucional, (1997) sentencia C-562 de 1997.

Corte InTeramericana de Derechos Humanos, Caso Apitz Barbera y otros ("Corte Primera de lo Contencioso Administrativo") vs. Venezuela, sentencia del 5 de agosto de 2008 .

Corte Interamericana de Derechos Humanos, Caso Barreto Leiva vs. Venezuela, sentencia de 17 de noviembre de 2009.

Corte Interamericana de Derechos Humanos, Caso Cabrera García y Montiel Flores vs. México, sentencia de 26 de noviembre de 2010.

Corte Interamericana de Derechos Humanos, Caso Cantoral Benavides vs. Perú, sentencia del 18 de agosto de 2000. 
Corte Interamericana de Derechos Humanos, Caso Castillo Petruzzi y otros vs. Perú, sentencia de 30 de mayo de 1999.

Corte Interamericana de Derechos Humanos, Caso Fernández Ortega y otros. vs. México, sentencia de 30 de agosto de 2010.

Corte Interamericana de Derechos Humanos, Caso Genie Lacayo vs. Nicaragua, sentencia de 29 de enero de 1997.

Corte Interamericana de Derechos Humanos, Caso Loayza Tamayo vs. Perú, sentencia del 17 de septiembre de 1997.

Corte Interamericana de Derechos Humanos, Caso Nadege Dorzema y otros vs. República Dominicana, sentencia de 24 de octubre de 2012.

Corte Interamericana de Derechos Humanos, Caso Radilla Pacheco vs. México, sentencia de 23 de noviembre de 2009.

Corte Interamericana de Derechos Humanos, sentencia de junio 23 de 2005 , Caso Yatama vs. Nicaragua.

Corte Interamericana de Derechos Humanos. Caso Ivcher Bronstein.

Corte Suprema de Justicia, Sala de Casación Penal en sentencia de junio 22 de 2016, M.P.: Fernández Carlier, radicado n. ${ }^{\circ} 42.720$.

Rodríguez, Gustavo Humberto citado por Younes Moreno Diego. Curso de derecho administrativo. Bogotá, Temis, 2007.

LEY FRANCESA de los 16 y 24 de agosto de 1790. Art. 17 "relativa a la organización judicial."

Saray Botero, Nelson. Procedimiento Penal Acusatorio. Bogotá, UniAcademia Leyer, 2017. 